\title{
New taxa of Pterostichini (Coleoptera: Carabidae) from Vietnam
}

\section{Новые таксоны Pterostichini (Coleoptera: Carabidae) из Вьетнама}

\author{
D.N. Fedorenko \\ A.H. Федоренко
}

\begin{abstract}
A.N. Severtsov Institute of ecology and evolution, Leninsky pr. 33, Moscow 119071 Russia.
Институт проблем экологии и эволюции им. А.Н. Северцова, Российская Академия Наук, Ленинский пр-т 33, Москва 119071, Россия. E-mail: dmitri-fedorenko@yandex.ru
\end{abstract}

KEY WORDS: Coleoptera, Carabidae, Pterostichini, Pterostichus, new genus, new subgenus, new species, replacement name, Vietnam, Oriental region.

КЛЮЧЕВЫЕ СЛОВА: Coleoptera, Carabidae, Pterostichini, Pterostichus, новый род, новый подрод, новый вид, замещающее название, Вьетнам, Ориентальная область.

ABSTRACT. New carabid beetle taxa of the tribe Pterostichini from Vietnam are described: genus Trigonaptus gen.n., subgenus Tausternus subgen.n. of the genus Pterostichus, and seven species, T. inaequalis sp.n., T. longiscapus sp.n., P. (T.) hoii sp.n., P. (Vietosteropus) kuznetsovi sp.n., P. (Steropanus) securipenis sp.n., $P$. (S.) pseudoglymmiger sp.n., and $P$. (S.) fossifrons sp.n. The replacement name Pterostichus $(S$.) boriskataevi nom.n. is proposed for junior homonym name $P$. (S.) kataevi Fedorenko, 2018.

РЕЗЮМЕ. Из Вьетнама описаны новые таксоны трибы Pterostichini (Carabidae): род Trigonaptus gen.n., подрод Tausternus subgen.n. рода Pterostichus и 7 видов - T. inaequalis sp.n., T. longiscapus sp.n., P. (T.) hoii sp.n., P. (Vietosteropus) kuznetsovi sp.n., P. (Steropanus) securipenis sp.n., P. (S.) pseudoglymmiger sp.n., and $P$. (S.) fossifrons sp.n. Замещающее название Pterostichus $(S$.) boriskataevi nom.n. предложено для младшего омонима $P$. (S.) kataevi Fedorenko, 2018.

\section{Introduction}

In course of exploring the ground beetle fauna of Vietnam, a few new species of the carabid genus Pterostichus Bonelli, 1810 have recently been described from this country [Fedorenko, 2017, 2018, 2019]. In the present paper we describe five new species of Pterostichus from there, three of the subgenus Steropanus Andrewes, 1937, one of the subgenus Vietosteropus Fedorenko, 2017, and another one of a new subgenus. For two more new species belonging to the 'Trigonotomi' group as defined by Roux et al. [2016] a new genus is erected. Besides, the re- placement name Pterostichus (Steropanus) boriskataevi nom.n. is here proposed for wrongly introduced junior homonym name Pterostichus $(S$.) kataevi Fedorenko, 2018 (non Pterostichus kataevi Kryzhanovskij, 1989).

Material was collected during several field trips and expeditions to highlands of Central and northern Vietnam, sponsored by the Joint Russia-Vietnam Tropical Centre.

Acronyms used are as follows: SIEE - the author's reference collection at A.N. Severtsov Institute of Ecology \& Evolution, Russian Academy of Sciences, Moscow; ZMMU - Zoological Museum of the Moscow State University; ZISP - Zoological Institute of Russian Academy of Science, St.-Petersburg.

The following parameters were analyzed: maximum body length measured between apices of closed mandibles and apex of elytra (BL); distance between apex $^{1}$ of elytron and discal pore d2 (D2); length of elytron, measured from the highest point of basal margin to apex (EL); maximum width of elytra (EW); width of head across eyes (HW); width of pronotum between apical (PA) or basal (PB) angles; length of pronotum along median line (PL); distance between apex and level of maximum width of pronotum, measured along mid-line (PLw); maximum width of pronotum (PW). Other abbreviations include US, umbilical seta, of USS, umbilical seta series running on elytral interval 9.

Measurements were taken using an eyepiece micrometer, to two decimal places. The means are given in round brackets for the ratios, with the number of measured specimens $(\mathbf{n})$ indicated for the first ratio in the description. All labels are printed. Data on labels of type specimens are in quotes.

\footnotetext{
${ }^{1}$ Wrongly specified 'base' [Fedorenko, 2017].
}

How to cite this article: Fedorenko D.N. 2020. New taxa of Pterostichini (Coleoptera: Carabidae) from Vietnam // Russian Entomol. J. Vol.29. No.1. P.38-52. doi: 10.15298/rusentj.29.1.06 
Results

Pterostichus Bonelli, 1810

Subgenus Tausternus Fedorenko, subgen.n. Figs 1-13.

Type species: Pterostichus hoii Fedorenko, sp.n.

DIAGNOSIS. A subgenus of Pterostichus recognizable in having prosternum with a very deep T-shaped sulcus, combined with metatibiae and metatarsi incrassate in male. Other features are as follows: Body apterous, medium-sized for the genus, shiny, metallic, violaceous blue. Head medium-sized, microphthalmic, with long genae; frontal foveae impunctate, in form of long and very deep round brackets; terminal palpomeres subfusiform. Mandibles moderately long, slender, nearly straight, with ventral scrobal ridge sinuate in dorsal view. Mentum tooth triangular and blunt. Antennomeres 4-11 pubescent, scape and pedicel unisetose, segment 3 without setae other than verticellate ones. Pronotum subcordate, with two basal sulci on each side, inner long, outer vestigial; disc convex up to lateral bead, without explanate lateral margin. Elytra connate, oblong, with apices blunt and narrowly separated along suture by an oblong fissure; humeri distinct, humeral angle obtuse, basal ridge outside stria 4. Elytral parascutellar striole missing. Prosternal process conspicuously beaded. Abdominal sternite VII with a long horn-like process in male. Legs slender; tarsomeres neither sulcate nor carinate laterally. Body on each side with fixed setae as follows: head: 2 supra-ocular, 1 clypeal; submentum -2 ; mentum -1 ; penultimate labial palpomere -2 ; maxillary stipes -2 ; pronotum - 2; elytra: parascutellar seta in stria 2, discal setae missing, apical setae -2 in stria 7 ; abdominal sternites IVVII -1 , sternite VII $-1\left(\sigma^{7}\right)$ or $2(+)$; legs: trochanter -1 ; metacoxa -3 ; profemur -3 , posterior; mesofemur -2 , anteroventral; metafemur - 1 , anteroventral basal; metatibia without outer setae; tarsomere 5 glabrous ventrally.

Aedeagus with right paramere small, apical orifice of median lobe left dorsolateral. Female reproductive tract similar to that of Pterostichus (Morphohaptoderus) Tscitschérine, 1898, except that spermathecal duct is extremely long and medially balled (receptacle subcylindric, gradually broadened apicad, meeting spermathecal duct at acute angle, with spermathecal gland duct entering just the corner).

DESCRIPTION. Body (Fig. 1) apterous, oblong, medium-sized.

Head medium-sized, without neck constriction, each side with a deep supra-ocular groove slightly surpassing eye; eyes small yet moderately convex, dorsolateral; genae long; posterior supra-ocular seta midway between posterior margin of eye and the angle. Frontal foveae C-shaped, long and deep. Antennae nearly filiform, length ratio of antennomeres 1-4 (1.13 : $0.6: 1: 0.8)$, scape with dorsal seta, pedicel with ventral seta.

Mandibular scrobe medially with a deep longitudinal sulcus reaching its apex. Mentum with two close setae at base of a simple and blunt median tooth. Genae ventrally just behind submentum deeply transversely grooved. Terminal labial palpomeres subfusiform.

Pronotum rather long, base and apex truncate, basal angles slightly obtuse and blunt, apical angles acute and porrect; basal bead missing, apical bead obliterate in middle third, lateral bead reaching posterolateral seta; basal and apical transverse impressions rather shallow. Inner basal sulci disappearing a third from base, diverging on each side of basal transverse impression and almost reaching base; outer sulcus half as long, running close to and anteriorly joining lateral bead, reaching and rather deep at basal margin; basal fovea impunctate. Posterolateral seta distinctly in front of base.

Elytron with a slight preapical sinuation and narrowly rounded apex, preapical plica well-developed yet internal and invisible in lateral view. Base truncate and narrow, without humeral tooth; humeri distinct yet apically rounded; sides diverging and straight in basal $1 / 2-2 / 5$. Reflexed lateral margin finely beaded up to apex, neither costate nor carinate, about as wide as interval 9. Striae deep impunctate or indistinctly crenulate. Intervals subequally wide, $9^{\text {th }}$ with $15-18$ US (mostly 16) arranged into anterior group in basal 1/3-1/4 (6-7 US, mostly six), posterior group behind middle, and one intermediate US.

Underside nearly smooth. Prosternal T-shaped sulcus very deep and almost reaching apex of prosternal process; this process apically rounded or subtruncate and conspicuously beaded; inclination posteriorly flat, wide dorsally, less so ventrally, constricted in between. Metepisternum ca. 0.83 times as long as wide. Abdomen entirely beaded laterally, sternite III with a wide and rather shallow median groove broadened slightly apicad.

Legs fairly slender and lightly armed with spiniform setae. Protibia slightly dilated apicad, apically with one posterior and two posterolateral spinules. Metatrochanter rounded apically, less than half as long as metafemur. Mesofemur with two subequally spaced anteroventral setae and two anterodorsal setae in apical two fifths; mesotibia with three outer setae, distal seta inserted closer to anterior ridge. Tarsomeres 1-4 each with one pair of latero-apical setae, tarsomeres 1-2 each with one pair of dorso-apical setae; mesoand metatarsomeres 1-4 with ventral setae rather sparse, being totally reduced in inner (posterior) row, except for 1-3 short setae survived on mesotarsomeres 1-4 and/or on metatarsomere 1 in some specimens.

Aedeagus (Figs 10-13) characteristic of Pterostichus.

Female genitalia and reproductive tract. Laterotergite with dense marginal setae; gonosubcoxite setulose along inner margin, with a few (four) strong setae along lateroapical margin. Gonocoxite falcate, with a double nematiform seta near apex and three ensiform setae, two ventral (outer) and one dorsal (inner), and 1-2 smaller additional setae at inner margin. Bursa copulatrix with three large yet fairly weak, contiguous, subtriangular sclerites, and a nodule, sphincter, near base of seminal canal. Spermatheca geniculate, seminal canal sclerotized at base, extremely long, serpentine, medially rolled into an incompact ball, meeting receptacle at acute angle; duct of spermathecal gland enters the corner; receptacle straight, subclavate, gradually broadened apicad.

Secondary sexual differences (of male): protarsomeres 13 dilated and biseriately squamose on ventral side as usual in the genus; abdominal sternite VII (Fig. 5) strongly modified, with a shallow round impression at middle and a fine longitudinal carina at its bottom that gives rise to a large, slightly flattened, horn-like process; meso- and metatibia (Figs 6-9) plurituberculate along both inner ridges, anterior and posterior; metatibia and metatarsus incrassate, tarsomeres cordiform.

NAME. Masculine, combination of Greek letter ' $\tau$ ' [tau] and 'sternum', referring to the very deep T-shaped impression of the prosternum.

DISTRIBUTION. The only species of the subgenus is known to occur in the Ngoc Linh Mt., Central Vietnam.

HABITS AND HABITATS. All specimens of Pterostichus hoii sp.n. were collected by pitfall traps in a monsoon forest at 1600-2150 m altitudes, together with some species of the subgenera Vietosteropus and Steropanus of Pterostichus. 
COMMENTS. This subgenus is monobasic. It is very distinctive in body appearance, including colouration; deeply transversely sulcate prosternum; frontal sulci unusual in shape, deep and wide; mandibles long and sinuate laterally; elytra apically separated and lacking discal setae; hind two leg pairs sexually dimorphic, with tarsi scarcely setose ventrally; abdominal sternite VII strongly modified in male; etc. On the other hand, there is only a little difference between this and some other subgenera of Pterostichus from Southeast Asia in body setation and female genital apparatus. Among them, Morphohaptoderus and probably also Tschitscherinea Berg, 1898 and Jedlickaia Sciaky, 1997 seem be closest to Tausternus subgen.n., all having the metacoxa trisetose (vs. bisetose in others).
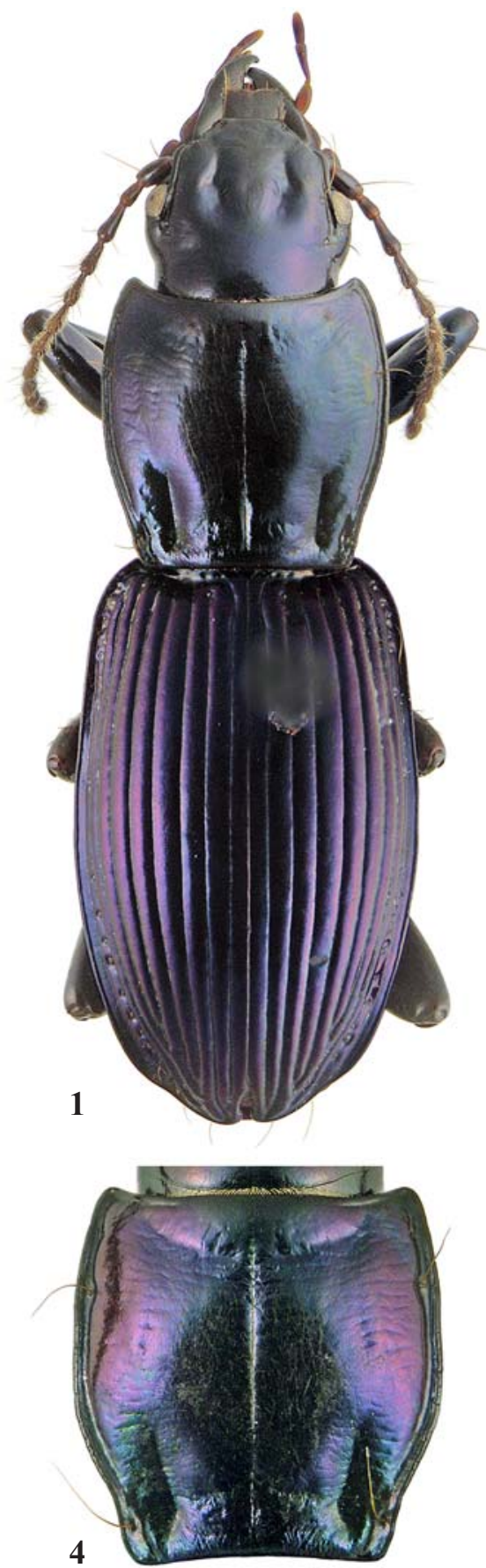

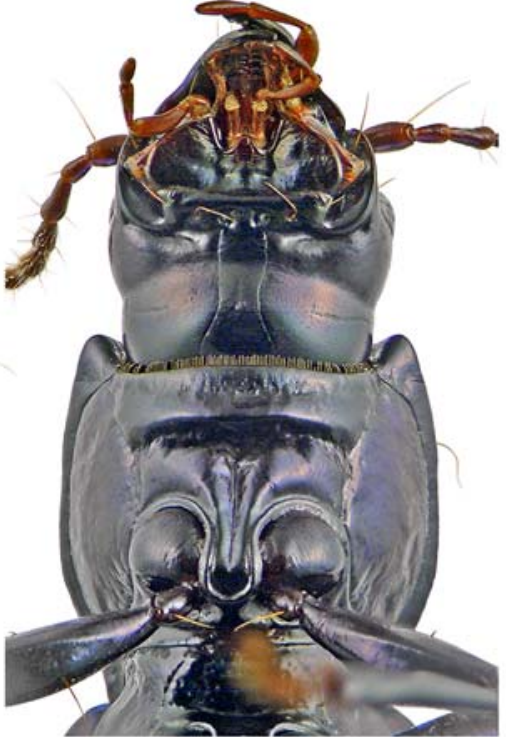

2

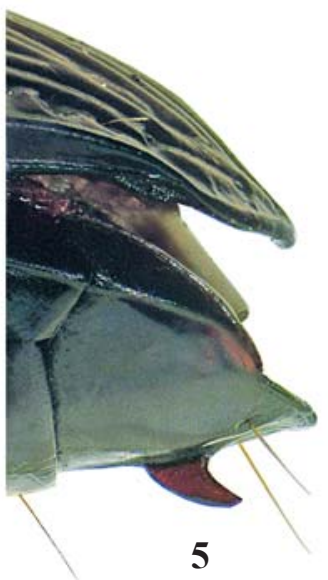

5

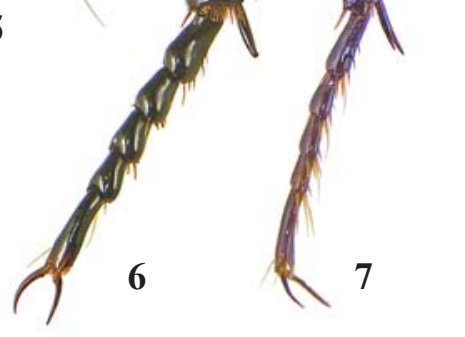

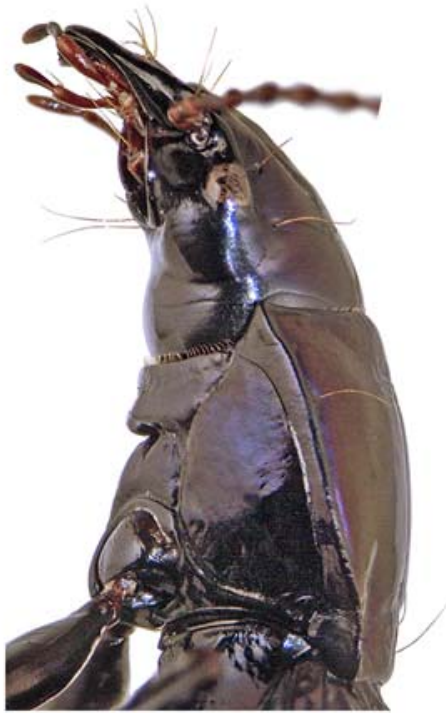

3

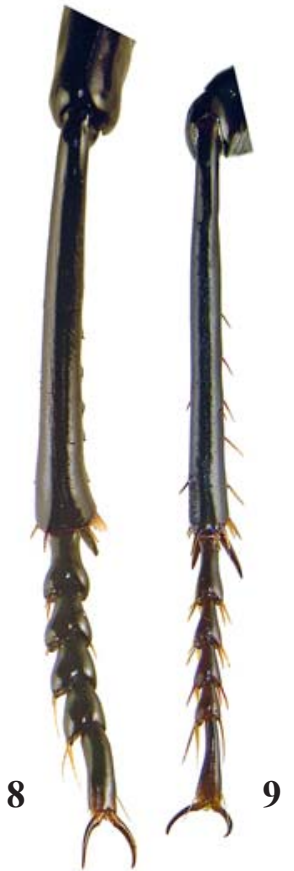

Figs 1-9. Pterostichus (Tausternus) hoii sp.n.: 1 - habitus of paratype + ; 2, 3 - head and pronotum; 4 - variant form of pronotum; 5 - body apex; 6-9 - left metatibia of male $(6,8)$ and female $(7,9) ; 1,4$ - dorsal aspect; 2 - ventral aspect; 3, 5, 8-9 - left lateral aspect; 6-7 - caudal aspect.

Pис. 1-9. Pterostichus (Tausternus) hoii sp.n.: 1 - габитус дорзально, паратип $9 ; 2,3$ - голова и переднеспинка; 4 - вариант формы переднеспинки; 5 - вершина тела; 6-9 - задняя левая голень самца $(6,8)$ и самки $(7,9) ; 1,4$ — дорзально; 2 - вентрально; 3, 5, 8-9 - слева; 6-7 - каудально. 


\section{Pterostichus (Tausternus) hoii Fedorenko, sp.n.} Figs 1-13.

MATERIAL. Holotype $\sigma^{7}$ and two paratypes ㅇ (ZISP), labelled: 'Vietnam, Kon Tum Prov[ince]., Central Highlands, 2-3 km W of Ngoc Linh Mt., $15^{\circ} 05^{\prime} \mathrm{N}, 107^{\circ} 57^{\prime} \mathrm{E}, 1700-1900 \mathrm{~m}, 25$.III14.IV.2004, A.V. Abramov'; two paratypes, $O^{7}+$ (SIEE) from the same exact locality, with label 'Vietnam, Kon Tum Prov., 2-3 km W of Ngoc Linh Mt., $15^{\circ} 05^{\prime} \mathrm{N}, 107^{\circ} 57^{\prime} \mathrm{E}, \mathrm{h}=1600-2150 \mathrm{~m}$, pitfall traps, 19.III-IV.2006, leg. A.Anichkin',

DESCRIPTION. As for the subgenus. Additional features: Dorsal microsculpture distinct, consisting of isodiametric meshes over head and elytra, and of small, slightly transverse meshes over pronotum.

Head: Genae distinctly longer than eyes, adjoining neck at very obtuse angle. Frontal foveae slightly diverging and deepened to the level of anterior margin of eye, then in form of oblong, wide and deep, foveae converging to and barely surpassing the level of posterior margin of eye; anteriorly extended onto clypeus into divergent shallow impressions. A superficial median V-or Y-shaped line between frontal foveae. Labrum rectangular, slightly transverse, sexsetose, apex more or less emarginate in form of a wide V.

Pronotum varying slightly in shape following sides ranging from slightly and evenly rounded in apical two thirds and subsinuate behind, with a subtle convexity near posterolateral seta, to nearly parallel in apical three fifths and then converging toward and sinuate a fifth from base. Median line fine yet deep, mostly reaching base and obliterate rather far from apex. Inner basal sulcus extended apicad into a very shallow line running parallel to lateral margin and disappearing a fifth from apex. PW/PL 1.03-1.09 (1.05, n=5), PW/HW 1.33-1.39 (1.36), PB PA $0.90-0.94(0.90, n=4)$, PLw/PL $0.36-0.40(0.38)$; in a female paratype (Fig. 4), PB/PA 0.82, PLw/PL 0.53.
Elytra broadest at or slightly behind middle, EL/EW 1.60-1.69 (1.64, n=5), EW/PW 1.16-1.23 (1.19). Striae deep impunctate or indistinctly crenulate. Intervals convex, $1 \mathrm{st}$ joining lateral bead at sutural angle; $7^{\text {th }}, 5^{\text {th }}$, and $3^{\text {rd }}$ confluent preapically in succession. Parascutellar seta distant rather far from the site of basal ridge.

Underside vaguely and sparsely punctate across mesoventrite; sometimes extreme sides of metaventrite and/or metepisternum, or propleura, or abdominal sternite III with a similar punctation.

Aedeagus (Figs 10-13): median lobe strongly curved at base, ventral margin with a large blunt tooth; apex moderately long, triangular in lateral view, rounded in dorsal view. Left paramere characteristic of Pterostichus, right paramere short, apically triangular and bulbous.

NAME. Patronymic, given after my good friend and colleague, Vietnamese geographer Dr. Nguen Dang Hoi.

\section{Pterostichus (Steropanus) securipenis Fedorenko, sp.n. \\ Figs 14, 19-20, 24, 27}

MATERIAL. Holotype $\sigma^{7}$ (ZMMU), labelled: 'Vietnam, Quang Nam Prov[ince]., Nam Gian Distr[ict]., Song Thanh Nat[io]n[al]. Park, $15^{\circ} 33^{\prime} 48^{\prime \prime} \mathrm{N} / 10^{\circ} 23^{\prime} 22^{\prime \prime} \mathrm{E}, \mathrm{h}=1050 \mathrm{~m}, 23 . \mathrm{IV}-11 . \mathrm{V} .2019$, leg. D. Fedorenko'. Paratype + (SIEE), same data, except for ' $15^{\circ} 33^{\prime} 48^{\prime \prime} \mathrm{N} / 107^{\circ} 23^{\prime} 22^{\prime \prime} \mathrm{E}, \mathrm{h}=1050 \mathrm{~m}$ '.

DIAGNOSIS. This species belongs to a species group defined by four derived characters, tarsomere 5 glabrous ventrally, frontal sulci very deep; pronotal lateral groove wide, deep and distinctly punctate, and elytral striae deep and punctate. The new species is distinguished from the other three species of the group, P. sulcatipennis Fedorenko, 2018; $P$. cavifrons Fedorenko, 2018; and P. alveolatus Fedorenko,

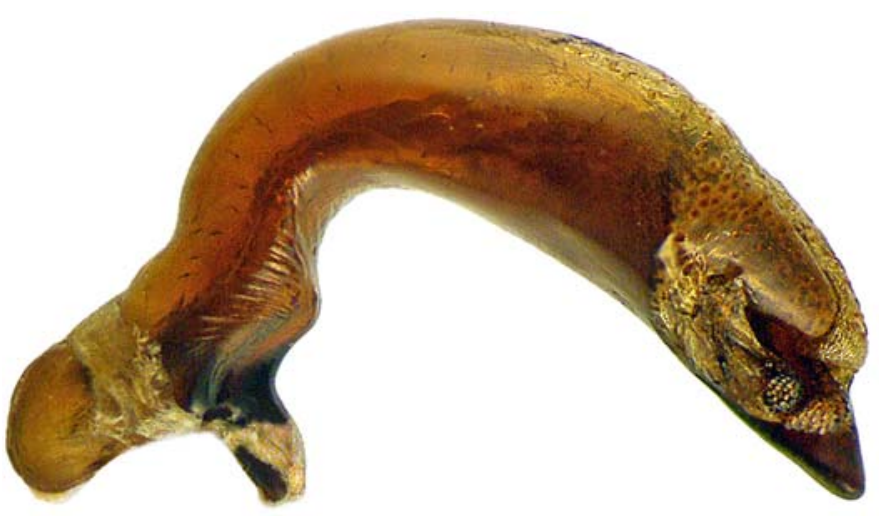

10

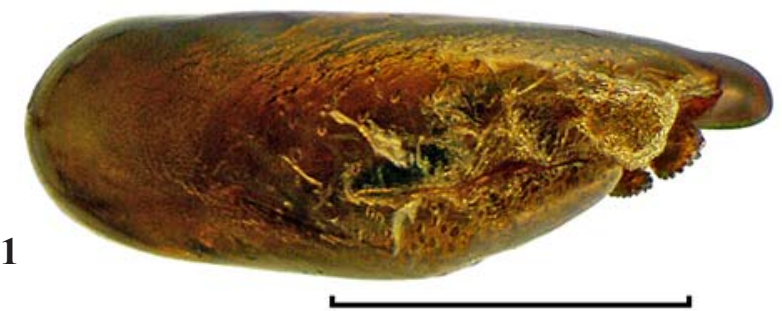

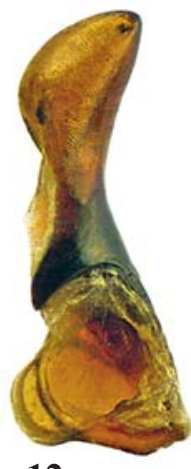

12

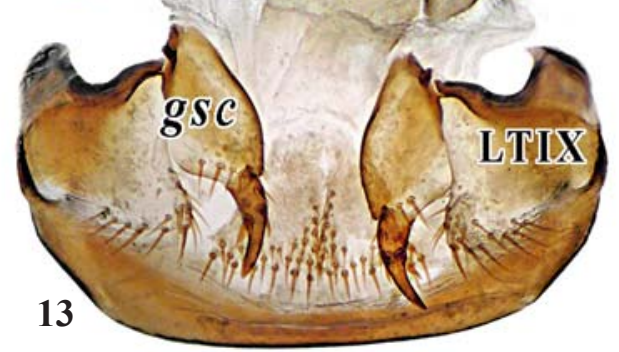

Figs 10-13. Pterostichus (Tausternus) hoii sp.n.: 10-11 - median lobe of aedeagus; 12 - right paramere; 13 - female genitalia and reproductive tract (spermathecal gland and major part of spermatheca removed), ventral aspect; 10 — left lateral aspect; 11 — dorsal aspect; $b c$ - bursa copulatrix; $g s c$ - gonosubcoxite; LTIX — laterotergite IX; $o v$ - common oviduct; $s b s$ - spermathecal basal sclerite; $s c$ seminal canal. Scale bars: $1 \mathrm{~mm}$.

Рис. 10-13. Pterostichus (Tausternus) hoii sp.n.: 10-11 - средняя доля эдеагуса; 12 - правая парамера; 13 - половой аппарат самки (большая часть сперматеки и железа сперматеки удалены), вентрально; 10 - слева; 11 - дорзально; $b c-$ копулятивная сумка; $g s c$ — гоносубкоксит; LTIX — латеротергит IX; ov — общий яйцевод; $s b s$ - базальный склерит сперматеки; $s c$ - семенной канал. Масштаб: 1 мм. 
2018 , by the elytral striae very coarsely punctate, two (vs. one) apical setae in interval 8 , and a distinctive aedeagus, with very wide, securiform apex of median lobe. Besides, $P$. sulcatipennis and $P$. cavifrons are distinguishable in the pronotum not or indistinctly cordate, with sides not or barely sinuate in front of basal angles. P. sulcatipennis is larger $(\mathrm{BL}>15.8 \mathrm{~mm}$ ), frontal sulci narrower and more shallow, and pronotal lateral groove narrower and finely punctate; $P$. cavifrons has pronotum smooth and mesotibia with a few additional setae just in front of one-row apical setal brush; $P$. alveolatus is distinctive in having elytral discal seta present (vs. missing in the other species).

DESCRIPTION. BL 12.5-12.8 mm. Body (Fig. 14) shiny black, with pronotal lateral groove and elytral striae dull due to coarse microsculpture. Legs red (paratype) or reddish brown (holotype), antennae reddish brown, paler apically, maxillary and labial palps red. Dorsal microsculpture meshed, superficial isodiametric, more (holotype) or less (paratype) distinct on head, distinct and moderately transverse on pronotum; pronotal lateral groove with coarse microsculpture, consisting of slightly longitudinal meshes. Elytral microsculpture superficial, consisting of narrow transverse meshes along middle of elytral interval (costa), turning into increasingly oblique meshes toward striae, and becoming coarse, slightly longitudinal, meshes at bottom of striae, with admixture of isodiametric meshes in strial punctures. Clypeus and pronotum densely or sparsely micropunctate, respectively.

Head: Eyes dorsal, small and prominent; gena about a third as long as eye, meeting neck at very obtuse angle. Frontal sulci smooth, diverging basad, in form of extremely deep, slightly oblong pits anteriorly, less deep behind, disappearing just posterior to the level of anterior supra-ocular seta. Supra-ocular groove very deep, straight anteriorly. Labrum subsinuate apically, apical setae equidistant inter se. Antennae just reaching pronotal base.

Penultimate labial palpomere quadrisetose (two fixed setae at inner margin plus two additional latero-apical setae, dorsal and ventral), except for a minute apical seta at outer margin. Terminal labial palpomere triangular, a third as wide at apex as long at inner margin in both sexes.

Pronotum cordate, PW/PL 1.28-1.29, PW/HW 1.571.58 , broadest $1 / 3-2 / 5$ from apex (PLw/PL 0.33-0.39); sides evenly rounded, sinuate just in front of basal angles. Base sinuate medially, oblique towards obtuse and blunt basal angles, slightly wider than apex, PB/PA 1.11-1.13. Apex rather deeply sinuate, barely convex just inside apical angles, without apical bead; apical angles porrect, with blunt apices. Lateral bead entire, fairly thick all along, lateral groove deep, wide, nearly flat, moderately and densely punctate, distinctly wider than lateral bead in medial two quarters, extended inside base into a fine and deep line almost reaching inner basal sulcus. These sulci very deep, running parallel to each other in basal third, obliterate just in front of base; outer basal sulcus missing. Median line very deep, sulcate, crenulate at bottom, reaching base and almost reaching apex. Disc smooth, coarsely punctate at base, confluently within inner basal sulci, densely inside, with punctures not quite reaching median line; $1-2$ punctures present outside basal sulcus. Anterolateral seta in lateral groove, posterolateral seta in basal angle.
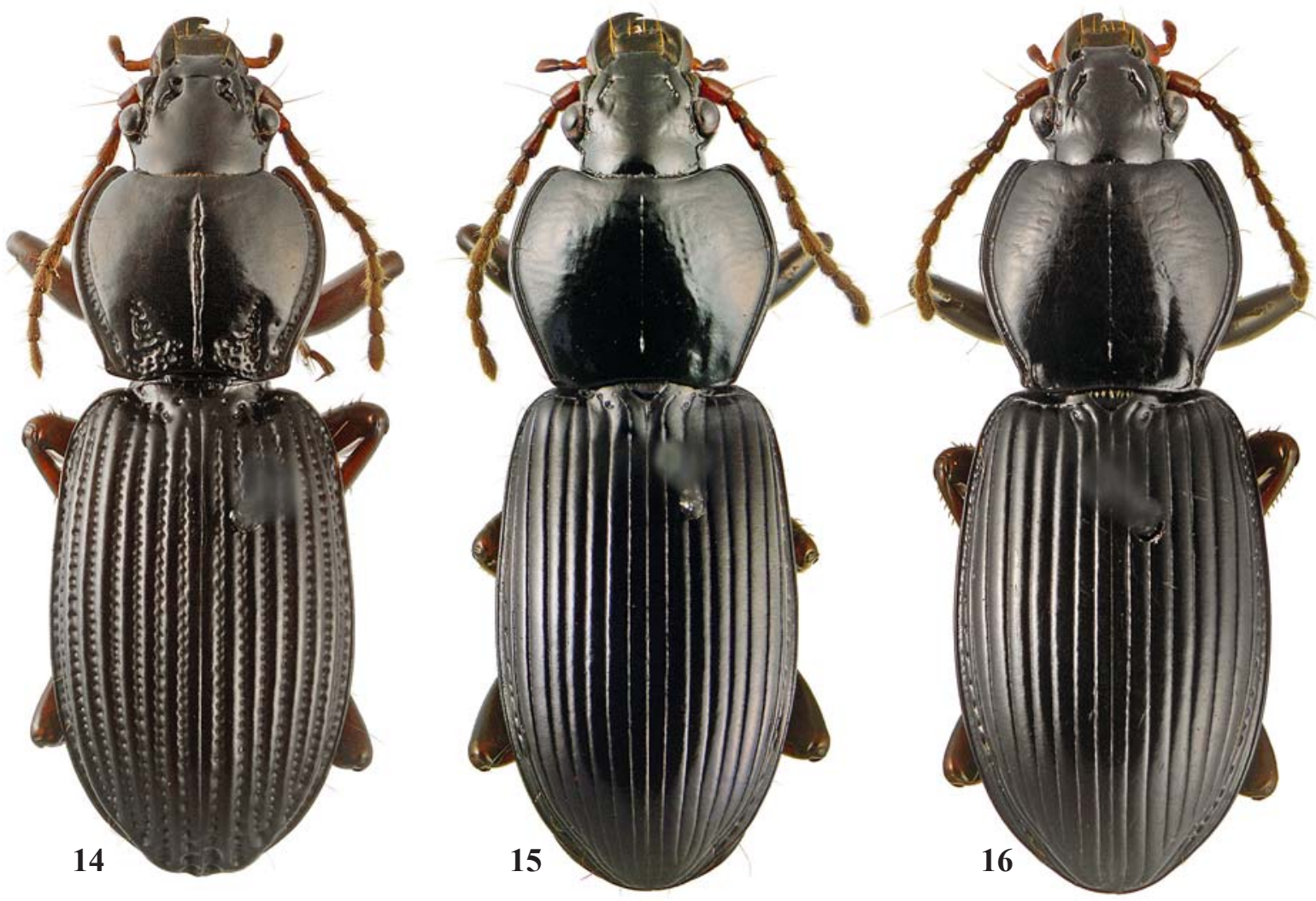

Figs 14-16. Dorsal habitus, holotypes: 14 - Pterostichus (Steropanus) securipenis sp.n; $15-P$. (S.) pseudoglymmiger sp.n.; $16-$ P. (S.) fossifrons sp.n.

Рис. 14-16. Габитус дорзально, голотипы: 14 - Pterostichus (Steropanus) securipenis sp.n.; 15 - P. (S.) pseudoglymmiger sp.n.; $16-P$. (S.) fossifrons sp.n. 
Elytra connate, elliptic, broadest behind middle, EW/EL 1.59-1.60, EW/PW 1.19-1.20, without preapical sinuation or internal plica; apices contiguous, apex otherwise slightly trilobed due to summit of apically confluent costae 2 to 7 projecting slightly apicad. Base narrow and oblique, humeri rounded, humeral tooth blunt and only traceable in posterodorsal view; basal ridge outside stria 3 , with a vestige between striae 4 and 5; humeral angle very obtuse. Striae 1-9 deep, very coarsely punctate, in apical third with punctures increasingly deep and large apicad; striae 1 and 7 with apical two punctures in form of large and very deep foveae; striae 16 adjoining basal ridge. Parascutellar striole missing. Intervals costate, $7^{\text {th }}, 5^{\text {th }}, 3^{\text {rd }}, 2^{\text {nd }}$ and 1 st confluent apicad in succession and then merging into a vanished lateral bead; intervals 8 and 9 vanished before apex. Reflexed lateral margin subequally narrow throughout its length. Parascutel- lar setigerous pore at base of stria 2, discal setae missing, two preapical setae in interval 8; USS: 18.

Underside. Prosternum with a fairly deep median groove terminating in a very deep pit $2 / 5$ from apical margin. Prosternal process in ventral view truncate, with fairly sharp angles; in lateral view rectangular and blunt; inclination wide, rounded in posterior view, slightly oblique and concave in lateral view. Abdominal lateral bead entire and conspicuous; sternite VII similar in both sexes. Mesepisternum coarsely and rather densely punctate in anterior half; metepisternum smooth or with a few coarse punctures.

Legs: profemur posteriorly trisetose, protibia barely dilated apicad, with three spinules at posterolateral edge, preapical spinule separate from two apical ones. Tarsi laterally neither carinate nor sulcate; tarsomere 5 glabrous ventrally. Protarsomeres 1-3 dilated and biseriately squamose ventrally
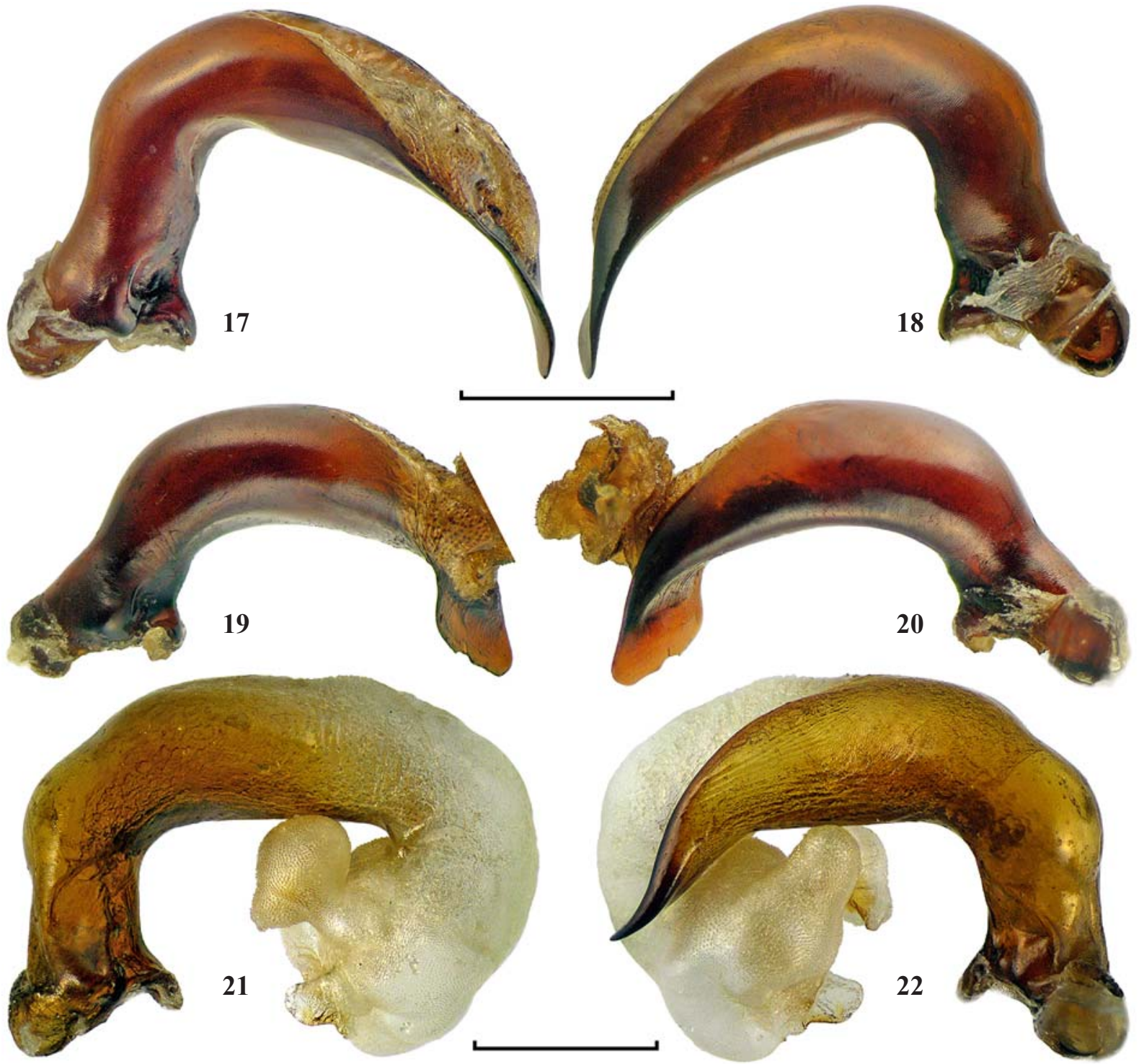

Figs 17-22. Aedeagus of Pterostichus (Steropanus) spp.: 17-18 - P. (S.) fossifrons sp.n.; 19-20 - P. (S.) securipenis sp.n.; 21-22 $P .(S$.) pseudoglymmiger sp.n., median lobe with everted and inflated internal sac; 17-20 - median lobe; 17, 19, 21 - left lateral aspect; 18, 20, 22 - right lateral aspect. Scale bars: $1 \mathrm{~mm}$.

Рис. 17-22. Эдеагус Pterostichus (Steropanus) spp.: 17-18 - P. (S.) fossifrons sp.n.; 19-20 - P. (S.) securipenis sp.n.; 21-22 $P$. (S.) pseudoglymmiger sp.n., средняя доля с вывернутым и раздутым внутренним мешком; 17-20 — средняя доля; 17, 19, 21 слева; $18,20,22$ - справа. Масштаб: 1 мм. 
in male; strongly dentate at apical angles in female. Mesotibia with a one-row apical setal brush.

Aedeagus (Figs 19-20, 24, 27): Median lobe arcuate. Apex conspicuously bent ventrad, oblique and very wide. Right paramere moderately long, subtriangular, with a narrow parallel-sided apex

DISTRIBUTION. Known from the type locality only.

NAME. Refers to the securiform apex of aedeagus median lobe.

HABITATS AND HABITS. Holotype was hand collected and paratype taken by pitfall trapping in a broad-leaved monsoon forest.

COMMENTS. Apical setal brush of the mesotibia has not been mentioned in the redescription of Steropanus [Fedorenko, 2018]. It is certain that the originally transverse and one-row setal brush $(P$. securipenis sp.n., $P$. sulcatipennis, P. pseudoviolaceus Fedorenko, 2018, P. obliteratus Fedorenko, 2018, and $P$. fossifrons sp.n.) at first evolved into that with a few additional setae appeared just above it in P. glymmiger (Andrewes, 1937), P. pseudoglymmiger sp.n., and $P$. cavifrons, and then into triangular and plurisetose setal brush in $P$. aequus (Andrewes 1937), $P$. asulcatus Fedorenko, 2018, and P. boriskataevi nom.n. as the additional setae became multiple.
Pterostichus (Steropanus)

pseudoglymmiger Fedorenko, sp.n.

Figs 15, 21-22, 25, 28.

MATERIAL. Holotype $\mathrm{O}^{7}$ (ZMMU), labelled: 'N-Vietnam, 40 $\mathrm{km}$ WNW of Lao Cai, env. Y Ty, Bat Xat N[ational]P[ark], 22 $37^{\prime}-$ $37.6^{\prime} \mathrm{N} / 103^{\circ} 37.3^{\prime}-38.3^{\prime} \mathrm{E}, \mathrm{h}=1600-1900 \mathrm{~m}, 16-21 . X .2018$, leg. D.Fedorenko'. Paratypes 2 우 (SIEE), same data, except for $22^{\circ} 37^{\prime} 36^{\prime \prime} \mathrm{N} / 103^{\circ} 37^{\prime} 32^{\prime \prime} \mathrm{E}, \mathrm{h}=1850 \mathrm{~m}, 4-14 . \mathrm{VI} .2019$.

DIAGNOSIS. This species is similar to $P$. glymmiger in appearance, being distinctive chiefly in having tarsomere 5 setose ventrally, pronotum without basal sulci, and elytral basal ridge slightly shortened. The other consubgeners with ventrally setose tarsomere 5 are distributed much more westerly, but $P$. obliteratus Fedorenko, 2018 only occurs in Vietnam. It is smaller, with $\mathrm{BL}<14 \mathrm{~mm}$, colouration black, pronotal sides convex towards base, with basal angles obtuse and rounded, elytral basal ridge entire, US being 18-19 in number, protibia less strongly armed, with 3-4 apical spinules along posterolateral edge, mesotibial brush one-row, etc. Metatibia with one external seta (vs. no seta) differentiates the new species from all eastern species of the subgenus.

DESCRIPTION. BL 15.3-16.3 mm. Body (Fig. 15) shiny black, elytra slightly violaceous along sides. Legs, antennae and palps rather dark reddish brown, femora infuscated to
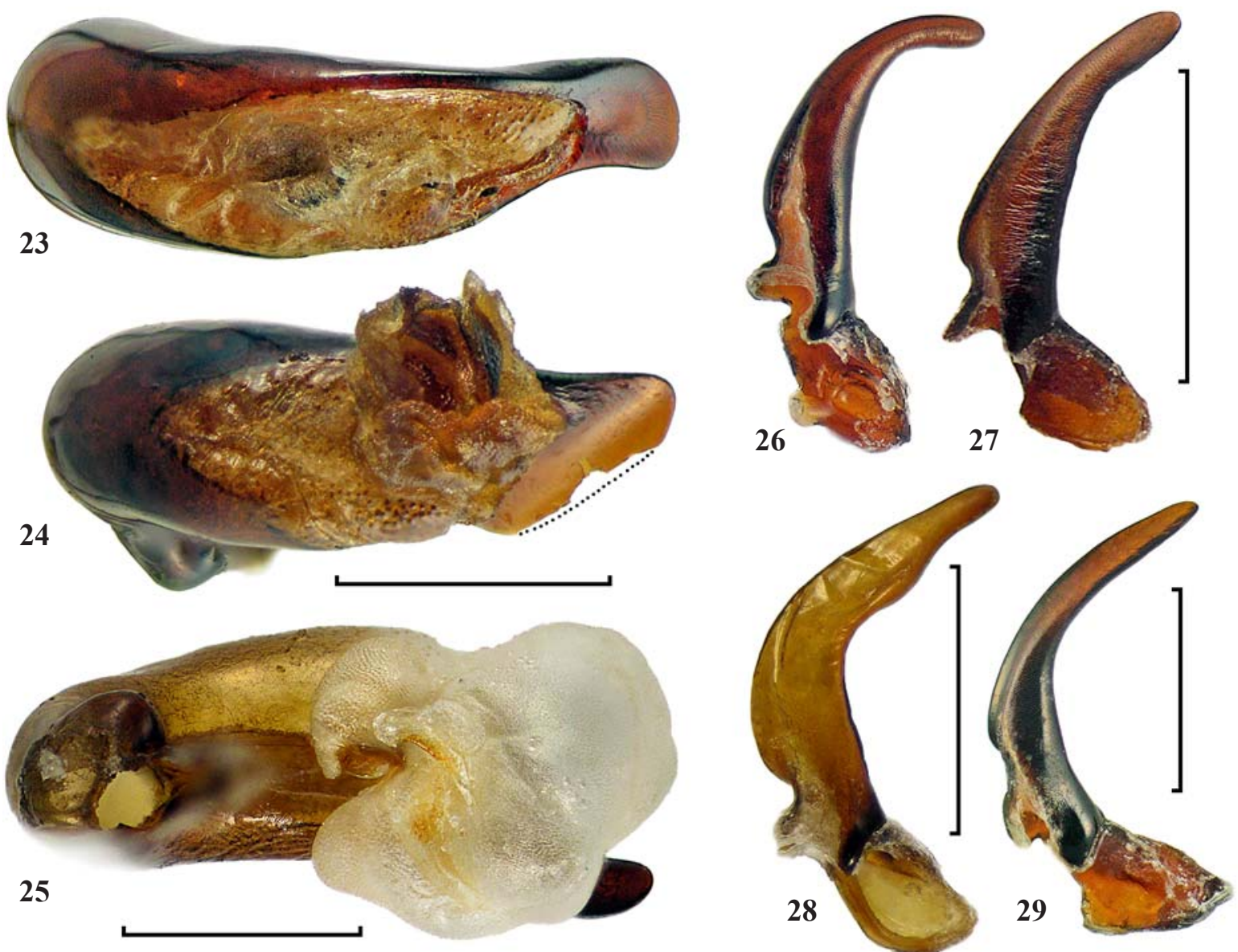

Figs 23-29. Aedeagus of Pterostichus spp.: 23, $26-P$. (Steropanus) fossifrons sp.n.; 24, 27 - P. (S.) securipenis sp.n. (apical margin slightly damaged); 25, $28-P$. (S.) pseudoglymmiger sp.n., median lobe with everted and inflated internal sac; $29-P$. (Vietosteropus) kuznetsovi sp.n.; 23-25 - median lobe, ventral aspect; 26-28 - inside of right paramere. Scale bars: $1 \mathrm{~mm}$.

Рис. 23-29. Эдеагус Pterostichus spp.: 23, 26 - P. (Steropanus) fossifrons sp.n.; 24, 27 - P. (S.) securipenis sp.n. (апикальный край слегка обломан); 25, 28 - $P$. (S.) pseudoglymmiger sp.n., средняя доля с вывернутым и раздутым внутренним мешком; 29 - $P$. (Vietosteropus) kuznetsovi sp.n.; 23-25 - средняя доля? вентрально; 26-28 - правая парамера, изнутри. Масштаб: 1 мм. 
nearly black but extreme apices. Dorsal microsculpture finemeshed; isodiametric, obliterate or hardly traceable on head; superficial yet distinct over pronotum and elytra, being barely or moderately transverse, respectively; pronotal lateral groove and reflexed lateral margin of elytra with nearly granulate isodiametric (pronotum) or barely longitudinal (elytra) meshes. Head densely micropunctate, pronotal punctation sparser and finer, with admixture of some larger punctures here and there; elytra very sparsely micropunctate.

Head: Eyes lateral, hemispherical, medium-sized; gena short, meeting neck at obtuse angle. Frontal sulci short, deep, crenulate, diverging basad, not reaching level of anterior supra-ocular seta. Supra-ocular groove deep, slightly incurved anteriorly. Labrum subsinuate apically, sexsetose, inner four setae closely set. Antennae almost reaching $(+)$ or slightly extended beyond $\left(O^{7}\right)$ pronotal base.

Penultimate labial palpomere trisetose (ventro-apical seta missing), except for a minute outer apical seta. Terminal labial palpomere more triangular in male than in female, 0.81 or 0.56 times as wide at apex as long at inner margin, respectively.

Pronotum subcordate, PW/PL 1.30-1.35 (1.33, n=3), PW/HW 1.62-1.69 (1.66), broadest two fifths from apex, PLw/PL 0.39-0.43 (0.41); sides evenly rounded in apical two thirds, indistinctly sinuate behind. Base sinuate medially, oblique towards obtuse and blunt basal angles, nearly as wide as apex, PB/PA 1.03-1.05 (1.04). Apex deeply sinuate, with almost indistinct convexity towards subrectangular and blunt apical angles. Apical bead fine, obliterate medially; lateral bead entire and fairly thick; lateral groove impunctate, narrow and deep, slightly extended inside base into a more or less distinct line. Median line very fine and shallow, slightly deeper near base, obliterate basally and apically. Disc smooth, basal sulci and transverse impressions, anterior and posterior, missing. Lateral setae, anterior and posterior, in lateral groove.

Elytra connate, oblong, broadest at middle, EW/EL 1.621.65 (1.64), EW/PW 1.12-1.18 (1.15), apices rounded combined, both preapical sinuation and internal plica slight. Base slightly oblique, humeri rather widely rounded, humeral tooth vestigial, being only traceable as a denticle between lateral bead and basal ridge in lateral view; basal ridge almost reaching stria 1 . Striae deep, impunctate, those 2-6 adjoining basal ridge; parascutellar striole missing. Intervals slightly convex, nearly flat a third from apex, all merging apically but intervals 4-6. Reflexed lateral margin narrow. Parascutellar setigerous pore at base of stria 2 , discal setae missing, stria 7 with one preapical seta, anterior, distant far from apex; USS: 24-25.

Underside. Prosternum almost smooth along middle. Prosternal process in ventral view truncate, with fairly sharp angles; in lateral view subrectangular; inclination wide, flat or barely concave, slightly constricted at middle, with lateral edges faintly beaded in dorsal half; in lateral view nearly vertical and barely concave. Abdominal lateral bead distinct and entire; sternite VII similar in both sexes. Mesepisternum very finely and densely punctate, metepisternum less so or smooth, abdominal sternites II-III indistinctly punctate or shallowly rugulose-punctate; ventral side otherwise smooth.

Legs: profemur posteriorly bisetose (basal seta missing), protibia distinctly dilated apicad, with 5-7 spinules at posterolateral edge. Tarsi laterally neither carinate nor sulcate; Tarsomere 5 with $2-3$ pairs of ventral setae. Protarsomeres $1-$ 3 dilated and biseriately squamose ventrally in male; strongly dentate at apical angles in female. Mesotibia with 2-3 additional setae just above one-row apical setal brush. Metatibia with one external seta, preapical.
Aedeagus (Figs 21-22, 25, 28): Median lobe geniculate. Apex narrow, subtriangular, apically rounded. Right paramere moderately long, boomerang-like, sinuate ventrally before a narrow apex. Internal sac without distinct apical sclerite (which may be a result of slightly teneral condition of the male specimen).

DISTRIBUTION. Known from the type locality only.

NAME. Refers to the similarity of this species to another consubgener, $P$. glymmiger.

HABITATS AND HABITS. All specimens were hand collected at the edge of a disturbed cloudy forest.

\section{Pterostichus (Steropanus) fossifrons Fedorenko, sp.n.} Figs 16-18, 23, 26.

MATERIAL. Holotype + (ZMMU), labelled: 'N-Vietnam, 40 $\mathrm{km} \mathrm{W}$ of Cao Bang, Phia Oac Mt., E[astern]-slope, $\mathrm{h}=1600-1800$ $\mathrm{m}, 22^{\circ} 36^{\prime} 27^{\prime \prime} \mathrm{N} / 105^{\circ} 52^{\prime} 0^{\prime \prime} \mathrm{E}, 22 . \mathrm{V}-6 . \mathrm{VI} .2018$, leg. A.Abramov'.

DIAGNOSIS. This species is similar to P. aequus (Andrewes, 1937) in appearance. According to the description, $P$. aequus has pronotal sides indistinctly sinuate, frontal sulci less deep, pronotal basal angles obtuse and more rounded, and impressed line (= outer basal sulcus extended into a remnant of basal bead) less deep than in P. glymmiger. In the new species, pronotal sides are distinctly sinuate just in front of basal angles, frontal sulci very deep, much deeper than those of $P$. glymmiger, pronotal angles in form of a blunt obtuse tooth, and the impressed line just as in P. glymmiger.

DESCRIPTION. BL $13.9 \mathrm{~mm}$. Body (Fig. 16) shiny black. Antennae, palps, femoral apices, tibiae and tarsi rather dark reddish brown. Dorsal microsculpture fine-meshed: isodiametric and almost imperceptible on head; superficial yet distinct over pronotum and elytra, consisting of barely transverse or narrow transverse meshes, respectively. Head rather densely micropunctate, pronotal punctation much sparser and much finer in part; elytral micropunctation indistinct.

Head: Eyes as in previous species. Frontal sulci indistinctly crenulate at bottom, very deep S-shaped, running parallel to each other just behind clypeus, strongly diverging on frons, slightly incurved and then abruptly disappearing just in front of the level of anterior supra-ocular seta; finest posterior extensions of frontal sulci diverging toward, running just inside, and disappearing just behind the level of postero-ocular setae. Supra-ocular groove deep, slightly incurved anteriorly. Labrum subsinuate apically, sexsetose, with inner four setae slightly separate from lateral ones. Antennae not quite reaching pronotal base.

Penultimate labial palpomere as in $P$. securipenis sp.n. Terminal labial palpomere two thirds as wide at apex as long at inner margin, somewhat pentagonal because of very convex outer margin.

Pronotum cordate, PW/PL 1.18, PW/HW 1.65, broadest two fifths from apex, PLw/PL 0.42; sides evenly rounded, sinuate just in front of basal angles. Base slightly sinuate medially, oblique towards basal angles, as wide as apex, PB/ PA 1.02; basal angles as fairly small, obtuse and blunt tooth. Apex gently sinuate, with a slight convexity towards subrectangular and blunt apical angles. Apical bead vestigial, extremely fine and hardly traceable, obliterate in middle third; lateral bead entire, rather thin; lateral groove crenulate at bottom, deep and narrow in basal half, barely wider and slightly more shallow in front. Inner basal sulci vestigial, almost indistinct yet long, running parallel to each other on basal two fifths, obliterate basally; basal sulcus, combined with a remnant of basal bead, as a rectangular impressed line separated by a fold from basal angle, this fold being as wide 
as lateral bead. Disc smooth, except for sparse, ill-defined transverse rugosities. Median line, transverse impressions and lateral setae as in previous species.

Elytra connate, elliptic, broadest medially, EW/EL 1.55, EW/PW 1.20, apices rounded combined, preapical sinuation imperceptible, plica internal. Base slightly oblique, humeri rather widely rounded, humeral tooth just traceable as a minute tubercle between lateral bead and basal ridge; this latter reaching stria 1. Striae deep, minutely punctate before apex, otherwise nearly smooth, $10^{\text {th }}$ finely yet distinctly punctate in basal three fifths; striae 1-6 adjoining basal ridge; parascutellar striole missing. Intervals convex, slightly more so laterally and apically, $7^{\text {th }}, 5^{\text {th }}$ and $3^{\text {rd }}$ confluent apicad in succession and then joining $2^{\text {nd }}$ and $8^{\text {th }} ; 1^{\text {st }}$ merging in lateral bead at sutural angle; $8^{\text {th }}$ costate and very narrow, subcarinate before preapical plica, as wide as $9^{\text {th }}$ and less than half as wide as $7^{\text {th }}$. Reflexed lateral margin narrow, slightly broadened apicad and barely convex in apical third. Parascutellar seta near base of stria 2 in interval 2, discal setae missing, stria 7 with one preapical seta, anterior, distant far from apex; USS: 23-25.

Underside impunctate, except for mesepisternum moderately and densely punctate across middle. Prosternum with a shallow median impression in front of procoxae. Prosternal process in ventral view truncate, with rounded angles; in lateral view rectangular, rounded apically; inclination wide, barely concave between just traceable lateral beads, slightly constricted at middle; vertical and straight in lateral view. Abdominal lateral bead entire; sternite VII similar in both sexes.
Legs as in P. pseudoglymmiger sp.n., except for protibia with 5-6 spinules at apex of posterolateral edge; tarsomere 5 glabrous ventrally; apical setal brush of mesotibia triangular, more than one-row; and metatibia glabrous at outer margin.

Aedeagus (Figs 17-18, 23, 26): Median lobe geniculate; apex in dorsal view large, with sides barely diverging apicad, widely rounded apically. Right paramere moderately long, crescent, more curved at apex.

DISTRIBUTION. Known from the type locality only.

NAME. Refers to very deep frontal sulci.

HABITATS AND HABITS. The holotype specimen was collected by pitfall trap in a montane broad-leaved forest.

\section{Pterostichus (Vietosteropus) kuznetsovi Fedorenko, sp.n. \\ Figs 29-30, 33-38.}

MATERIAL. Holotype (ZMMU) and paratype (SIEE), $\sigma^{7} \sigma^{7}$, labelled: 'Vietnam, Quang Nam Prov[ince]., Nam Gian Distr[ict]., Song Thanh Nat[io]n[al]. Park, $15^{\circ} 34^{\prime} 07^{\prime \prime} \mathrm{N} / 107^{\circ} 23^{\prime} 13^{\prime \prime} \mathrm{E}, \mathrm{h}=1010$ m, 23.IV-11.V.2019, leg. D. Fedorenko'.

DIAGNOSIS. With characters of the subgenus and of the formerly monobasic gialaiensis-group [Fedorenko, 2017]. Its nominal species, $P$. gialaiensis Fedorenko, 2017, is distinctive chiefly in having pronotal basal fovea and sulci impunctate and aedeagus distinctive. Additional differences are superficial: pronotal basal angles more rounded apically, explanate lateral margin barely narrower, inner basal sulcus deep. Aedeagus: median lobe with apex widely rounded and projecting laterad
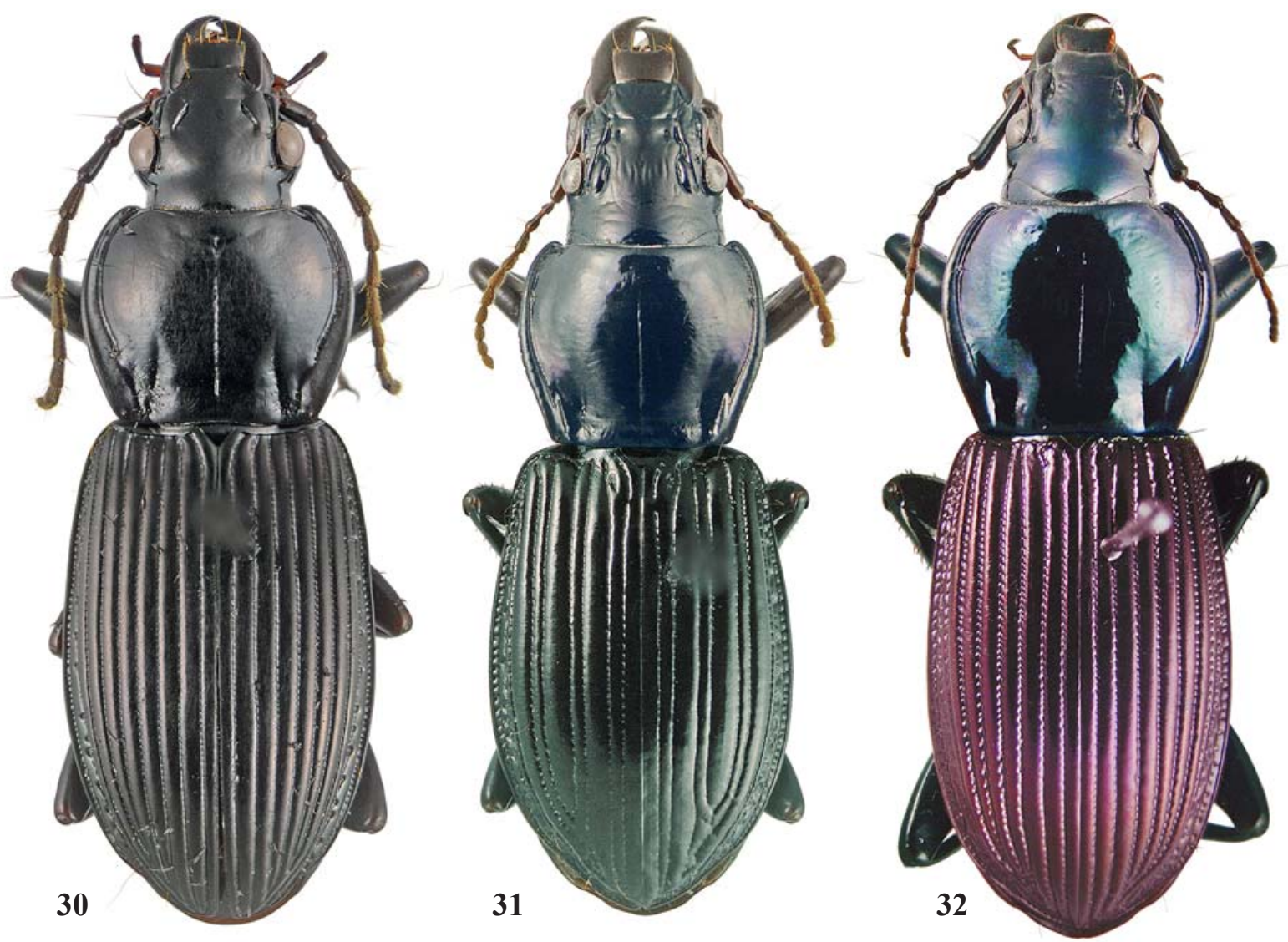

Figs 30-32. Dorsal habitus, holotypes: 30 - Pterostichus (Vietosteropus) kuznetsovi sp.n.; 31 - Trigonaptus inaequalis gen. et sp.n.; $32-T$. longiscapus sp.n.

Рис. 30-32. Габитус дорзально, голотипы: 30 - Pterostichus (Vietosteropus) kuznetsovi sp.n.; 31 - Trigonaptus inaequalis gen. et sp.n.; $32-T$. longiscapus sp.n. 
beyond everted and inflated internal sac; this latter with PBR much larger and directed apicad and PBL slightly different in shape due mainly to vesicles $l v 1$ and $l v 2$ and $l v 3$ distinct.

Besides, the submentum is bisetose in $P$. gialaiensis (vs. quadrisetose in the new species). However, more material is necessary to decide whether this difference is species-specific or it may have come from individual variability of $P$. gialaiensis.

DESCRIPTION. BL 17-17.1 mm. Body (Fig. 30) shiny black. Antennae brownish toward apices. Dorsal microsculpture absent from head, very superficial on pronotum and elytra, consisting of very small meshes, pronotal meshes being rectangular and moderately transverse, elytral ones more transverse, fusiform, becoming dense transverse lines here and there. Explanate lateral margin of pronotum with hardly traceable microsculpture consisting of slightly longitudinal meshes.

Head: Eyes convex, gena 0.37 times as long as eye. Frontal sulci very deep impunctate, diverging and slightly S-shaped, nearly parallel just before and behind, reaching the level of anterior supra-ocular seta. Neck constriction indistinct, hardly traceable only laterally. Submentum quadrisetose.

Pronotum subquadrate, PW/PL 1.32, PW/HW 1.55, evenly rounded on sides, less so in basal two fifths, with basal angles obtuse and slightly blunt; basal margin gently concave at middle; apex evenly concave between narrowly rounded apical angles. Explanate lateral margin in form of a wide bead in front of anterolateral seta, otherwise gradually broadening basad and rather wide in basal half. Lateral grooves deep in apical three quarters and almost directly extended into outer basal sulci; these more shallow, slightly C-shaped (convexity inward), obliterate just basally. Inner basal sulci moderately deep, straight, running on and barely converging in basal third. Basal fovea finely and moderately densely punctate in and between basal sulci. Median line moderately deep, almost obliterate near base and apex. Both transverse impressions, basal and apical, imperceptible. Anterolateral seta inserted in lateral groove, basolateral seta close to basal angle.

Elytra elliptic, broadest behind middle, EW/EL 1.581.62, EW/PW 1.14-1.15; sides poorly rounded in basal half, preapical sinuation and internal preapical plica distinct, apices truncate combined, with tips blunt. Humeral angle obtuse. Striae deep, densely punctate, punctures becoming increasingly large from very fine in stria 1 to medium-sized in stria 10; parascutellar striole missing. Intervals convex, subcostate to costate laterally and apically; $8^{\text {th }}$ as wide as $7^{\text {th }} ; 7^{\text {th }}$, $5^{\text {th }}$ and $3^{\text {rd }}$ confluent apicad in succession; $1^{\text {st }}$ merging into
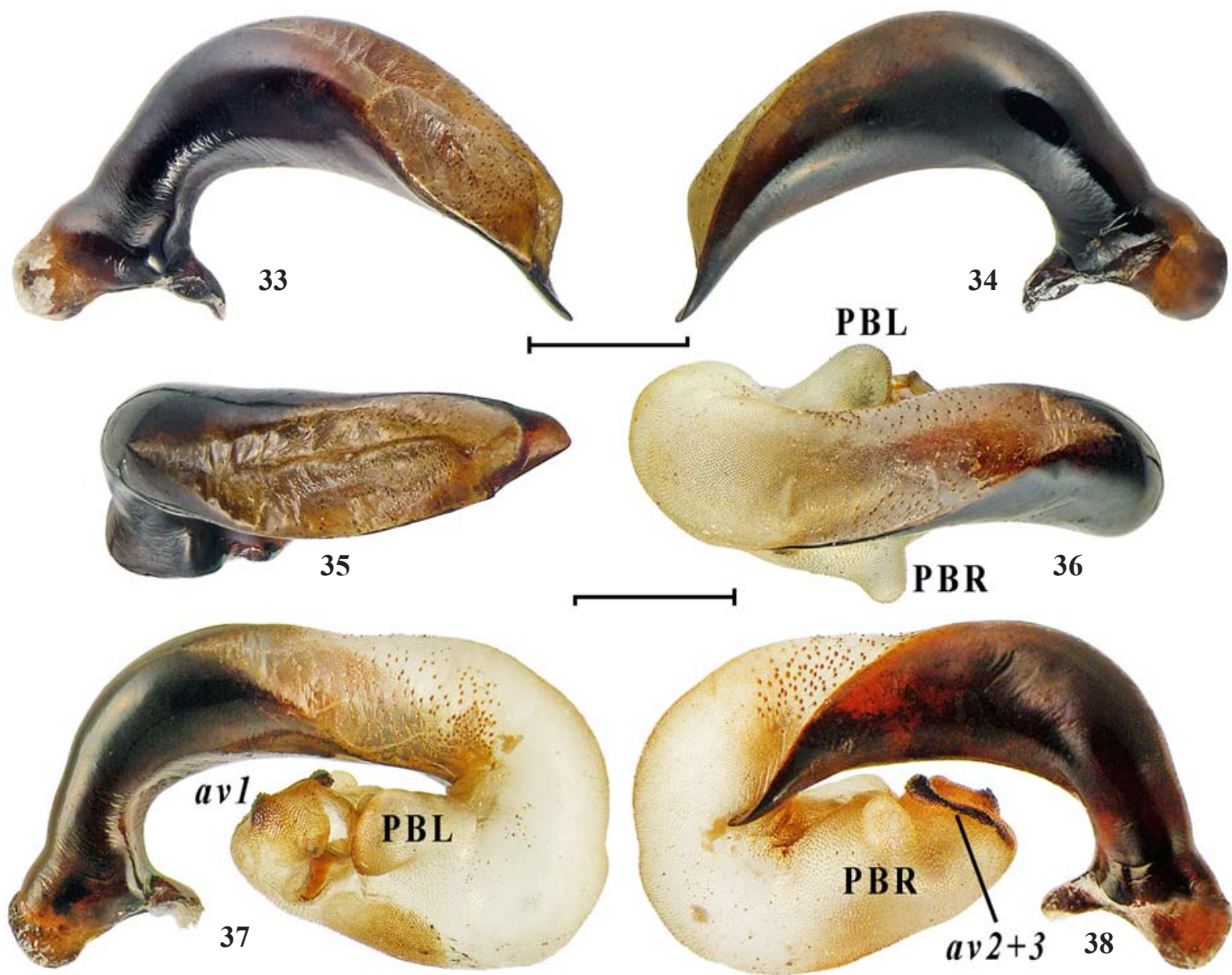

Figs 33-38. Aedeagus of Pterostichus (Vietosteropus) kuznetsovi sp.n.: 33-35 - median lobe; 36-38 - median lobe with everted and inflated internal sac; 33, 37 — left lateral aspect; 34, 38 — right lateral aspect; 35-36 — dorsal aspect; $a v 1$, av2+3 — apical vesicles; PBL — left preapical bulb; PBR - right preapical bulb. Scale bars: $1 \mathrm{~mm}$.

Рис. 33-38. Эдеагус Pterostichus (Vietosteropus) kuznetsovi sp.n.: 33-35 - средняя доля; 36-38 - средняя доля с вывернутым и раздутым внутренним мешком; 33, 37 - слева; 34, 38 - справа; 35-36 - дорзально; av1, av2+3 - апикальные пузырьки; PBL - левый предвершинный пузырь; PBR - правый предвершинный пузырь. Масштаб: 1 мм. 
while 3rd separate from lateral bead apically; no costa or carina outside interval 9. Parascutellar seta just behind basal ridge. D2/EL 0.44-0.45. USS: 20-22.

Underside. Prosternal process truncate apically, in lateral view rectangular or almost so; declivity flat, with lateral edges sharp and faintly beaded in ventral half. Abdomen entirely beaded on sides, except base of sternite II. Mes- and metepisternum moderately and densely punctate, sides of metaventrite with sparse punctures; abdominal sternites IIIV laterally with a few clusters of fine and dense punctures.

Legs: metatibia externally glabrous; mesotarsomeres 1-2 sulcate on each side of a conspicuous outer carina, metatarsomeres 1-3 similarly sculptured except that the carina is blunt.

Aedeagus (Figs 33-38): median lobe with apex triangular and slightly pointed, without right dorso-apical tooth. Right paramere crescent and fairly long. Everted and inflated internal sac: left preapical bulb (PBL) entire, $l v 3$ missing; right preapical bulb (PBR) rather small and set perpendicular to median lobe in dorsal view. Two apical vesicles present, small $a v 1$ and $a v 2+a v 3$.

DISTRIBUTION. Only known from the type locality.

HABITATS AND HABITS. Both specimens were collected by pitfall traps in a monsoon broad-leaved forest.

NAME. Patronymic, given after my good friend and colleague, chief of the Joint Russia-Vietnam Tropical Centre, botanist Dr. Andrei Kuznetsov.

\section{Trigonaptus Fedorenko, gen.n.} Figs 31-32, 39-52.

Type species: Trigonaptus inaequalis Fedorenko, sp.n.

DIAGNOSIS. The new genus includes two Trigonoto$m a$-like species recognizable in the combination of very long antennal scape; lateral lobes of mentum pointed and much produced beyond median tooth; labrum with setae equidistant and basal membrane not or slightly exposed due to clypeus truncate to gently sinuate apically; terminal labial palpomere triangular; metepisterna short following apterous condition; antennal pedicel with ventral seta. For details see also 'Comments' below.

DESCRIPTION. Body (Figs 31-32) apterous, mediumto large-sized.

Head bisetose on each side, subtriangular, large and long, with neck incrassate; neck constriction missing or indistinct. Eyes small, longer than genae. Clypeus bisetose, transversely hexagonal, with apex truncate or slightly V-shaped, frontoclypeal suture fine, transversely straight. Frontal sulci deep, short to long. Antennae geniculate, short, reaching the level of basal 1/4-2/5 pronotum; scape very long, as long as antennomeres 2 to 5 combined, distinctly surpassing eye behind, with dorsal seta; pedicel with ventral seta.

Labrum obtrapezoidal, sexsetose; apical sinuation even or V-shaped. Mandibular scrobe with a deep longitudinal median sulcus. Maxillary stipes bisetose. Mentum short, apically beaded; lateral lobes slightly pointed and projecting far beyond median tooth; the tooth short and wide, more or less bifid, with a seta at each angle tooth and small yet deep labial pits behind. Submentum bisetose, very short, costate medially or nearly throughout; gula wide, trapezoidal, almost reaching sides of head basally. Ligula long and wide, bisetose apically, paraglossae membranous, dorsal, barely longer than ligula. Terminal maxillary palpomere fusiform; terminal labial palpomere triangular, $1 / 2-3 / 5$ as wide at apex as long at inner margin; penultimate labial palpomere bisetose.

Pronotum subcordate, without basal bead; apical bead obliterate except at apical angles. Reflexed lateral margin rather narrow, costate or almost so; lateral groove obliterate in basal quarter; basal foveae smooth, flat and deep between basal sulci, outer sulcus separated by a fold from lateral groove. Anterolateral seta in lateral groove, posterolateral seta close to basal angle.

Elytra connate, elliptic, each with internal plica and a distinct preapical sinuation. Humeri distinct. Basal ridge inwardly reaching stria 2 or 3 , humeral angle obtuse or very so. Striae deep punctate; parascutellar striole missing or vestigial. Chetotaxy: parascutellar seta in interval 2 near stria 2 , discal setae missing, two apical setae in stria 7; USS continuous, consisting of 18-24 US.

Ventral side coarsely punctate along sides, including propleura, mes- and metepisterna and abdominal sternites IIVI. Prosternal process without marginal bead. Mesoventrite toothed or with a fine ridge in front of each mesocoxa. Metepisternum as long as wide or barely transverse. Abdominal sternites VI-VII deeply sulcate along bases; sternite VII bisetose in male, quadrisetose in female.

Legs, including setation, as in Trigonotoma Dejean, 1828: profemur posteriorly bisetose (basal seta missing), protibia slightly dilated apicad, apically with two posterolateral spinules and one posterior spinule. Mesofemur with two subequally spaced anteroventral setae and two anterodorsal setae in apical two fifths; mesotibia with three outer setae, distal seta inserted closer to anterior ridge. Metacoxa bisetose laterally (inner seta missing), metatrochanter rounded apically, less than half as long as metafemur, asetose; metafemur with basal anteroventral seta; metatibia with 1-3 outer setae. Tarsomeres 1-4 each with one pair of latero-apical setae, tarsomeres 1-2 each with one pair of dorso-apical setae; tarsomere 5 with three pairs of ventral setae. Meso- and metatarsi anteriorly (outwardly) with a more or less distinct lateroventral sulcus bearing a row of setae running on tarsomeres 1-2 or 1-3; either lateral carina and laterodorsal sulcus missing or the latter indistinct. Tarsomeres 1-3 dilated and biseriately squamose in male.

Aedeagus (Figs 39-52): median lobe more or less curved in lateral view, right paramere short. Internal sac divided into two isolated parts, internal sac proper and a more or less developed accessory proximal bulb.

NAME. Masculine, an abbreviated combination of the generic names Trigonotoma and Pareuryaptus, referring to the similarity of the new genus to the two taxa.

DISTRIBUTION. The member species of the genus are only known from single locality each, either a mountain in southern Vietnam or a small plateau in Central Vietnam.

HABITS AND HABITATS. Occurs in monsoon forests.

COMMENTS. The 'Trigonotomi' group includes one Papuan genus, Leiolesticus Roux et al., 2016 and six Oriental ones, Lesticus Dejean, 1828; Trigonotoma Dejean, 1828; Euryaptus Bates, 1892; Nesites Andrewes, 1939 (= Aloma Andrewes, 1931); Pareuryaptus Dubault et al.; 2008; and Trigonaptus gen.n. All these taxa (Nesites, Euryaptus and Leiolesticus not seen) share significant, mostly derived, characters as follows: body medium to large-sized and glabrous; abdominal sternites sulcate basally; gula wide to very wide basally; mandibles rather large, with apex narrow, strongly pointed and incurved; legs, including protibiae, fairly slender, with rather weak spinuous armature; terminal labial palpomere broadened apicad, either subtriangular in both sexes or securiform in male; metacoxa bisetose or unisetose laterally; metatrochanter asetose; tarsomere 5 setose ventrally; protarsomeres 1-3 dilated and biseriately squamose ventrally in male. For other features see Roux et al. [2016].

The new genus is distinctive from the other taxa of 'Trigonotomi' in having a peculiar character combination 
(Table). To trace probable relationships within this group, we leave below autapomorphies of Trigonaptus gen.n. $\left(7^{2}\right)$ and Pareuryaptus $\left(11^{1} 12^{1}\right)$ out of consideration. Character $14^{1}$ is also of little value for the purpose because it is highly functional and has been developed many times within Carabidae in course of evolution.

Characters $1^{0}-4^{0}$ have been retained by Lesticus (and probably also Leiolesticus) only, which invites the basalmost position of the genus within the 'Trigonotomi', and multiple symplesiomorphies $\left(5^{0}-10^{0} 14^{\circ}\right)$ also argue in favour of this hypothesis. Accordingly, synapomorphies $1^{1}-4^{1+2}$ support monophyly of the other genera, character $4^{2}$ being probable autapomorphy of Trigonotoma. The genus otherwise is the most primitive within this lineage, since plesiotypic characters are as many as apotypic ones $\left(6^{0} 9^{0} 10^{0} 5^{1} 7^{1} 8^{1}\right)$. Euryaptus, Pareuryaptus and Nesites share apotypic characters $5^{1} 6^{1} 9^{1} 10^{1}$ and Nesites is distinctive within this trio in the combination of plesiotypic character $8^{0}$ and apotypic $14^{1}$. Euryaptus and Pareuryaptus seem to be closely related because their distribution patterns are vicariant, western or eastern, respectively, and character $7^{0} / 7^{1}$ only serve for discrimination between the two taxa; this difference is also not deep because the antennal scape varies from species to species of Pareuryaptus considerably in length. This suggests also that the short scape may have evolved into a long one more than one time in the group considered.
The characters Trigonaptus gen.n. share with Trigonotomal Nesites/ Pareuryaptus are $7^{1} 9^{0} 10^{0} 13^{1 /} 6^{1} 7^{1} 8^{0} 14^{1 /} 6^{1} 7^{1}$, respectively. Except for character 14, the characters shared are four for the first couple, three for the second, and two for the third. This may suggest that the new genus is closer to Nesites or Trigonoto$m a$, but this hypothesis much depends on whether some of the characters $6^{1} 9^{1} 10^{1} 13^{1}$ and also $7^{1}$ have been developed in parallel or not. Some plesiotypic characters $\left(5^{0} 8^{0} 9^{0} 10^{\circ}\right)$ point to a considerable primitiveness of the new genus.

Because characters of the aedeagus and its internal sac vary within Trigonaptus gen.n. and Trigonotoma considerably, they only contribute a little to understanding the relationships between Trigonotoma, Pareuryaptus and Trigonaptus gen.n. Those genitalic features may be useful for the purpose nevertheless, that define the main two aedeagus types, the Trigonotoma-type and the Pareuryaptus-type. The former is generally defined by a simple internal sac, combined with the apex of the median lobe being large, obtrapezoidal, conspicuously curved to the right, with a dorsal carina. The Pareuryaptus-type includes the internal sac double, with an accessory proximal bulb, and the apex of the median lobe symmetric, widely rounded, very short to indistinct, without dorsal carina. Trigonaptus gen.n. and some species of Trigonotoma, e.g., T. perraudieri Bates, 1889 match this aedeagus-type well, except that the median lobe has a large apex.

Table. Distribution of selected characters within the 'Trigonotomi' group. Таблица. Распределение некоторых принаков в группе 'Trigonotomi'.

\begin{tabular}{l|c|c|c|c|c|c|c|c|c|c|c|c|c|c}
\hline \multicolumn{1}{c|}{ Character } & $\mathbf{1}$ & $\mathbf{2}$ & $\mathbf{3}$ & $\mathbf{4}$ & $\mathbf{5}$ & $\mathbf{6}$ & $\mathbf{7}$ & $\mathbf{8}$ & $\mathbf{9}$ & $\mathbf{1 0}$ & $\mathbf{1 1}$ & $\mathbf{1 2}$ & $\mathbf{1 3}$ & $\mathbf{1 4}$ \\
\hline Leiolesticus & & & & & & & & & & & & & & \\
\hline Lesticus & $?$ & $?$ & 0 & 0 & 0 & 0 & 0 & 0 & 0 & $?$ & $?$ & $?$ & $?$ \\
\hline Trigonotoma & 1 & 1 & 1 & 2 & 1 & 0 & 1 & 1 & 0 & 0 & 0 & 0 & 1 & 0 \\
\hline Trigonaptus gen.n. & 1 & 1 & 1 & 1 & 0 & 1 & 2 & 0 & 0 & 0 & 0 & 0 & 1 & $1^{\prime}$ \\
\hline Nesites & 1 & 1 & 1 & 1 & 1 & 1 & 1 & 0 & 1 & 1 & 0 & 0 & 0 & $1^{\prime}$ \\
\hline Pareuryaptus & 1 & 1 & 1 & 1 & 1 & 1 & 1 & 1 & 1 & 1 & 1 & 1 & 0 & 0 \\
\hline Euryaptus & 1 & $?$ & 1 & $?$ & 1 & 1 & 0 & 1 & 1 & 1 & $?$ & $?$ & $?$ & 0 \\
\hline
\end{tabular}

Characters (states: 0, plesiotypic; 1-2, apotypic; 1', homoplasy):

1. gula: (0) moderately wide, with its sides barely diverging and base only a third as wide as moderately wide neck — (1) brodeaned much basad, with sides strongly diverging, only slightly narrower at base than incrassate neck;

2. profemur: posteriorly (0) trisetose - (1) bisetose owing to basal seta lost;

3. antennae: (0) long, distinctly surpassing elytral base - (1) short, not surpassing basal 1/4 pronotum;

4. mentum: (0) moderately transverse, epilobes well-developed, as very obtuse median tooth at inner margin of lateral lobes; these slightly surpassing mentum tooth in front - (1) transverse, epilobes strongly reduced in size, modified into a tooth-like dilation of apical bead just outside median tooth, lateral lobes more or less pointed and much surpassing median tooth anteriorly - (2) very transverse; lateral lobes truncate and very short, on a level with median tooth;

5. mentum tooth: (0) more or less bifid, with angles distinct and apical margin slightly concave — (1) subtruncate to much rounded, with angles very blunt to missing;

6. elytron parascutellar striole: (0) well-developed - (1) vestigial to totally reduced (this character state actually means quite otherwise, i.e., stria 1 anteriorly obliterate and directly extended into a well-developed parascutellar striole);

7. antenna: scape (0) short, shorter than antennomeres 2 and 3 combined - (1) very long, not or barely surpassing mid-eye level, mostly shorter than antennomeres 2 to 5 combined - (2) extremely long, distinctly surpassing eyes behind, as long as antennomeres 2 to 5 combined;

8. terminal labial palpomere: (0) subtriangular - (1) securiform in male;

9. labral setae: (0) subequally spaced - (1) lateral setae distant far from inner four;

10. abdominal sternite VII: (0) quadrisetose in female - (1) bisetose in both sexes;

11. metacoxa: (0) laterally bisetose, with inner seta only missing - (1) unisetose, posterolateral seta lost;

12. antennal pedicel: (0) with ventral seta - (1) glabrous;

13. meso- and metatarsi: (0) without anterolateral setae - (1) with a row of anterolateral (outer) setae;

14. body: (0) macropterous, metepisterna distinctly longer than wide - (1) apterous, metepisterna short. 
Based on these facts and suggestions, the relationships of the genera considered is likely to be Lesticus + (Trigonotoma $+($ Trigonaptus gen.n. $+($ Nesites $+($ Pareuryaptus + Euryaptus)))).

\section{Trigonaptus inaequalis Fedorenko, sp.n.}

Figs 31, 44-48, 50, 52.

MATERIAL. Holotype $\sigma^{7}$ (ZMMU), labelled: 'S Vietnam, Lam Dong Prov[ince]., Bi Doup-Nui Ba [Nature] Reserve, $12^{\circ} 07^{\prime} \mathrm{N} /$ $108^{\circ} 39^{\prime} 20^{\prime \prime}$ E, Bi Doup Mt., N[orthern] slope, $\mathrm{h}=1700-1900 \mathrm{~m}$, 10.IV.2008, leg.D.Fedorenko'. Paratypes $30^{7} \sigma^{7}$ (SIEE), same data except 15-16. or 19-22.IV.2008.

DIAGNOSIS. Medium-sized species recognizable in body black; forebody with slight violaceous lustre; eyes prominent; clypeus truncate apically; frontal sulci long, each with an oblong tubercle running between supraocular setae just inside the sulcus; pronotal lateral edge crenulate; elytral intervals 3, 5 and 7 distinctly to much wider than others; metatrochanter apically pointed, etc.

DESCRIPTION. BL 14.7-16 mm, body (Fig. 31) black and slightly dull. Head and pronotum with slight violaceous lustre, elytra laterally with imperceptible bronzed reflections. Knees and tarsi deep reddish brown; antennomeres 1-4 dark brown, their bases, antennomeres 5-11, and palps red. Sides of labrum translucent with red. Dorsum densely microscopically punctate, meshed microsculpture distinct, consisting of very small meshes, isodiametric on head, isodiametric or barely transverse on pronotum, slightly transverse, with admixture of isodiametric meshes, on elytra.

Head incrassate, large, together with closed mandibles about a fourth longer than pronotum, without neck constriction. Gena half as long as small and prominent eye; eyes lateral and slightly dorsal, with very deep supraocular groove just inside. Clypeus truncate apically, frontoclypeal suture hardly traceable, barely convex basad, with a shallow median pit and a deeper one on each side. Frontal sulci long, very deep and impunctate, slightly S-shaped in front the level of anterior supraocular setae, then forking; forks running nearly parallel to each other, outer fork adjoining while inner fork curved towards and disappearing just inside posterior supraocular seta; a conspicuous oblong tubercle between them. Frons on each side behind clypeus with a small and fairly deep pit, between eyes with seven short and shallow striae. Neck laterally with a small deep pit behind eye; sides of head dorsal to gular sutures coarsely transversely rugose. Antennae reaching basal $2 / 5$ pronotum.

Labrum evenly sinuate between slightly pointed angles; distances between three apical setae on each side, inner, intermediate, and lateral, ca. 0.7:1. Mandibles with ventral scrobal ridge shallowly sinuate anteriorly and thence obtusely angulate basally. Mentum tooth slightly bifid, pits rather deep yet rudimentary, without openings. Submentum basally with a very deep groove between gular sutures. Terminal labial palpomere half as wide at apex as long at inner margin.

Pronotum subcordate, PW/PL 1.24-1.33 (1.29, n=4), PW/HW 1.47-1.53 (1.49), broadest two fifths from apex, PLw/PL 0.39-0.43 (0.41); sides rounded, indistinctly sinuate in front of obtuse and blunt basal angles; lateral edge slightly crenulate. Base truncate, as wide as apex, PB/PA 0.97-1.01 (0.99), its sides lateral to inner basal sulci gently oblique and barely sinuate. Apex truncate, apical angles slightly acute and a little projecting; apical bead obliterate except in lateral sixth. Reflexed lateral margin costate, bead-like, slightly broadened basad. Basal foveae rather deep, inner and outer basal sulci moderately deep and nearly smooth, outer running on basal third, inner barely longer yet anteriorly forking or extended directly into a shallow sublateral line that almost reaching apex.

Elytra rather short, EW/EL 1.54-1.57 (1.55), EW/PW $1.19-1.23$ (1.22), with a fairly deep impression across bases of intervals 3-5. Humeri distinct. Basal ridge inwardly reaching stria 3, humeral angle very obtuse. Striae deep, finely to moderately punctate, stria 9 coarsely punctate; parascutellar striole vestigial, very short. Stria 1 subinterrupted anteriorly (i.e., not quite fused to primary parascutellar striole), 1-6 or 4-6 uneven apically and obliterate just before apex, with $5^{\text {th }}$ and $6^{\text {th }}$ mostly confluent and abruptly disappeared a fifth from apex; stria 6 anteriorly opposite humeral angle. Intervals subconvex, $3^{\text {rd }}, 5^{\text {th }}$ and $7^{\text {th }}$ much wider than others; $7^{\text {th }}$ very convex before and behind; $8^{\text {th }}$ very narrow, subcarinate in basal three fifths, carinate behind. USS: 18-19.

Underside densely, in part confluently punctate, abdominal sternites II-VI with clusters of dense punctures. Mesoventrite with a fine ridge in front of mesocoxae. Metepisternum as long as wide. Abdominal transverse sulci obliterate medially, sometimes sternite VII with transverse sulcus traceable throughout.

Metatrochanter apically pointed and adherent to metafemur. Meso- and metatarsomeres $1 / 2 / 3$ with $3-4 / 2 / 1$ anterolateral setae, respectively.

Aedeagus (Figs 44-48): median lobe slightly geniculate, with apex very narrow, in dorsal view barely curved to the left and slightly capitate; right paramere very short and rounded apically. Internal sac (Figs 50,52) with proximal bulb small and distinct in right lateral view only.

NAME. Refers to the elytral intervals of unequal width.

DISTRIBUTION. Known from the type locality only.

HABITS AND HABITATS. All specimens were hand collected in a monsoon broad-leaved forest.

\section{Trigonaptus longiscapus Fedorenko, sp.n.} Figs 32, 39-43, 49, 51.

MATERIAL. Holotype $\sigma^{7}$ (ZMMU) and paratype $\sigma^{7}$ (SIEE), labelled: 'Vietnam, Gia Lai Province, $\sim 50 \mathrm{~km} \mathrm{~N}$ of An Khe, Kon Chu Rang Nat[ure]. Reserv[e]., $14^{\circ} 30-31^{\prime} \mathrm{N} / 108^{\circ} 32^{\prime} \mathrm{E}, \mathrm{h}=1000$ $1040 \mathrm{~m}, 24 . \mathrm{V}-2 . \mathrm{VI} .2016$, D.Fedorenko leg.'. Paratypes $20^{7} 0^{\top}$,,+ (SIEE), "Vietnam, Gia Lai Province, $\sim 80 \mathrm{~km} N$ of Pleiku, Kon Chu Rang Nat.Res., $14^{\circ} 29^{\prime} 15^{\prime \prime} \mathrm{N} / 108^{\circ} 34^{\prime} 15^{\prime \prime} \mathrm{E}, \mathrm{h} \sim 1010 \mathrm{~m}, 28$.III6.IV.2016, A.Abramov leg.' (one male teneral).

DIAGNOSIS. Fairly large species; dorsum shiny, head and pronotum bright violaceous, elytra purple-red (rather violaceous in holotype only) and slightly iridescent; clypeus slightly V-shaped apically; head smooth, frontal sulci short; pronotal lateral edge even; elytral intervals subequal in width; metatrochanter apically rounded.

DESCRIPTION. As for previous species except as follows: BL 21.5-24.5 mm, body (Fig. 32) bright metallic. Legs and antennae black, protarsi reddish brown, antennomeres 811 gradually paler apicad. Head and elytra impunctate, pronotal micropunctation just traceable, largely indistinct; head without meshed microsculpture, pronotal microsculpture indistinct in apical half, very superficial, consisting of moderately transverse meshes, in basal half; elytral microsculpture consisting of very dense transverse lines.

Head smaller, as long as pronotum, with a subtle neck constriction. Eyes lateral, less prominent. Clypeus apically emarginate in form of very wide ' $\mathrm{V}$ ', frontoclypeal suture fine yet distinct. Frontal sulci similar yet short, vestigial behind the level of anterior supra-ocular setae, with only a vestige of inner fork. Surface smooth, sides of head dorsal to gular sutures finely rugulose. Antennae reaching basal $1 / 4$ pronotum. 
Labrum apically with a V-shaped emargination; setae subequally spaced. Mandibles with nearly straight ventral scrobal ridge. Mentum tooth slightly bifid, labial pits very deep, with small openings. Submentum basally with a shallow transverse groove. Terminal labial palpomere three fifths as wide at apex as long at inner margin.
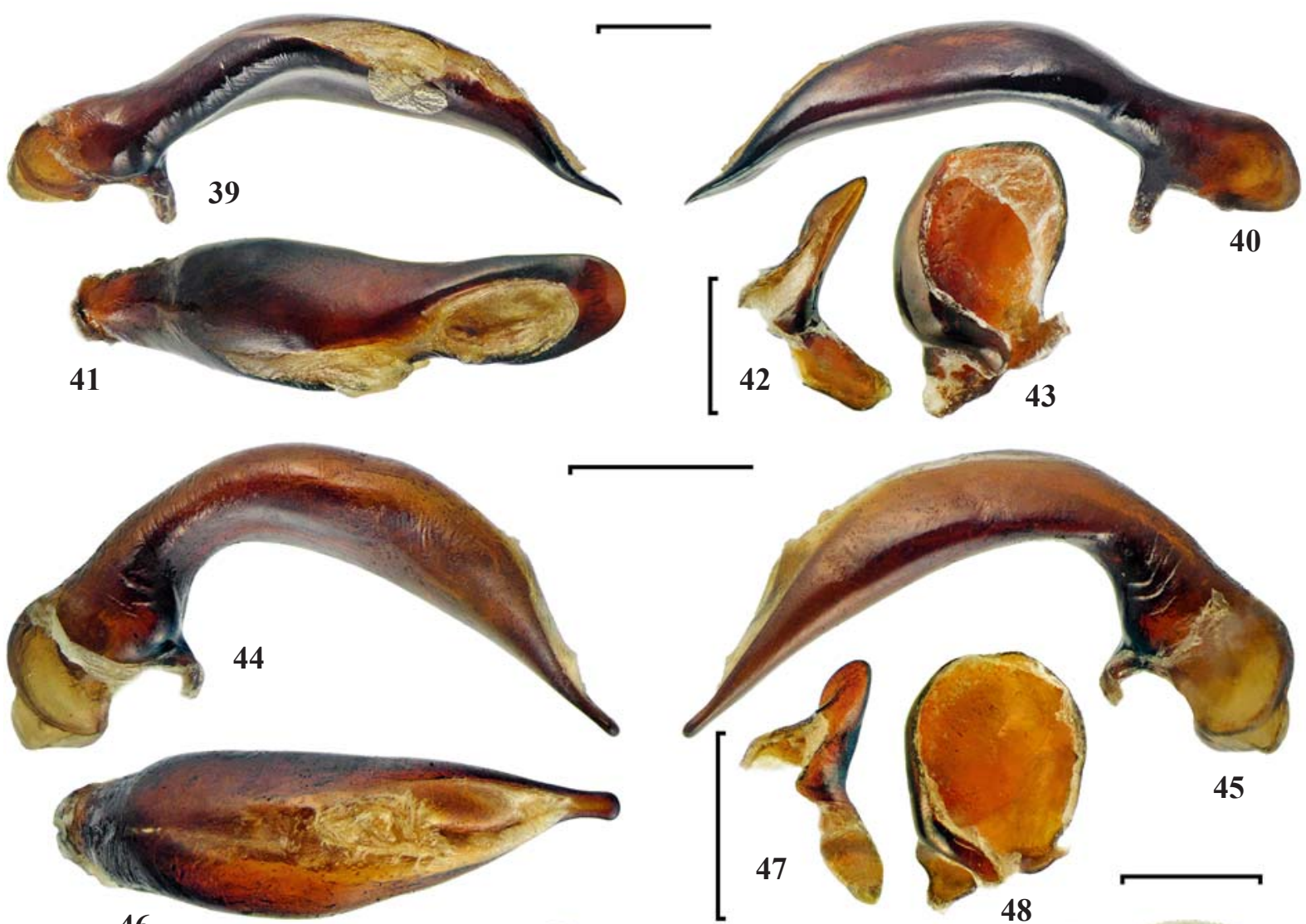

46
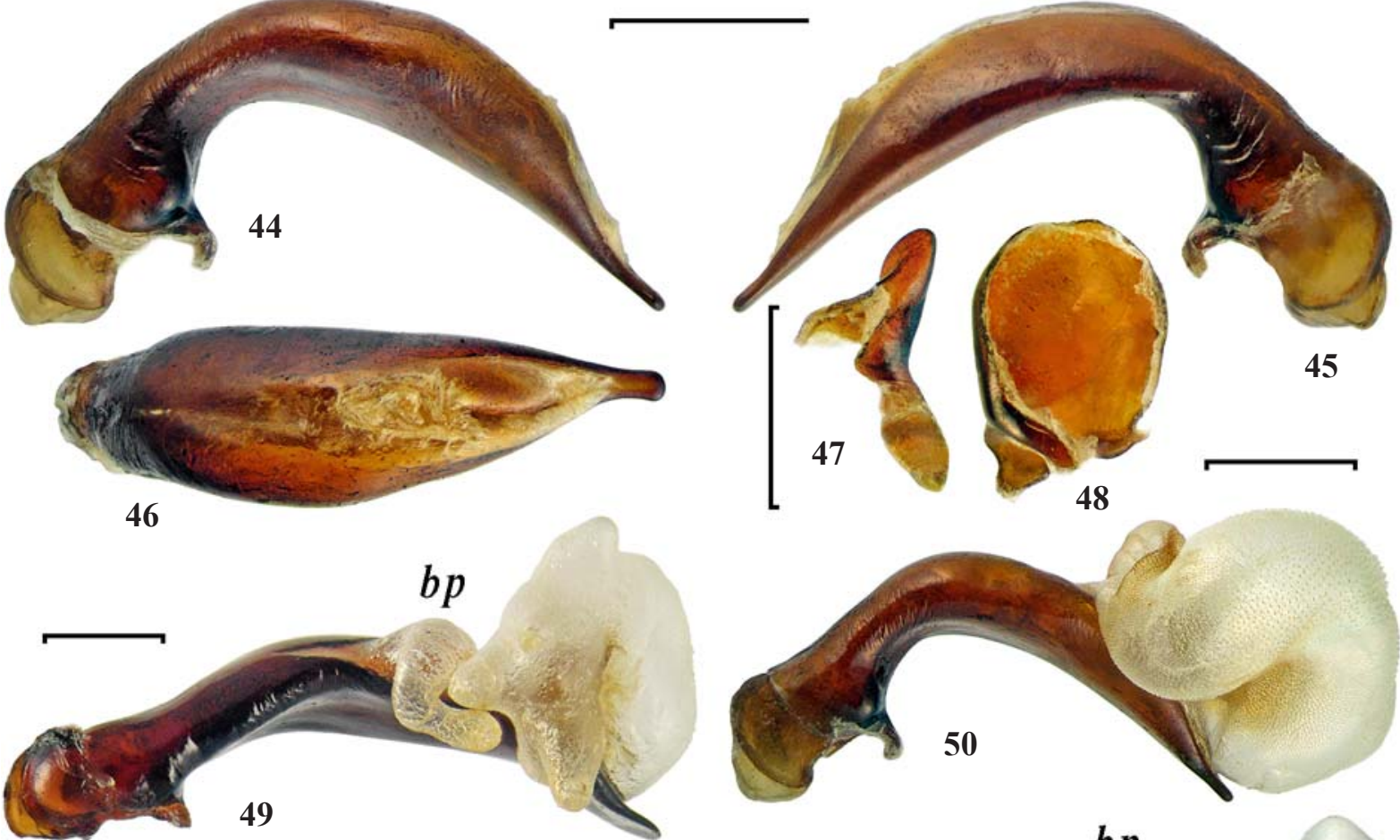

49

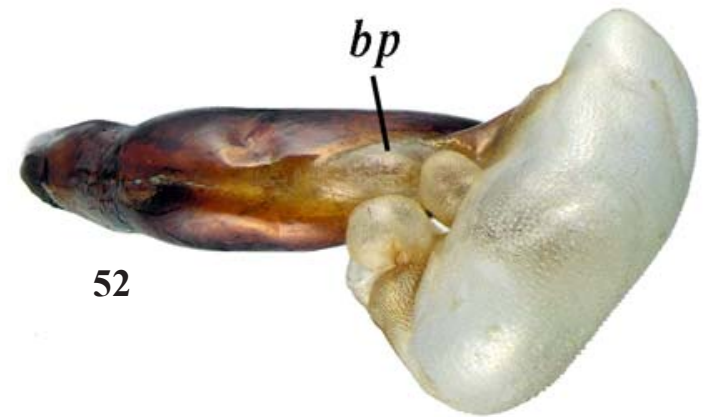

Figs 39-52. Aedeagus of Trigonaptus gen.n.: 39-43, 49, $51-T$. longiscapus sp.n.; 44-48, 50, 52 - T. inaequalis sp.n.; 39-41, 4446 - median lobe; 42, 47 - inside of right paramere; 43, 48 - inside of left paramere; 49-52 — median lobe with everted and inflated internal sac; 39, 44, 49-50 - left lateral aspect; 40, 45 - right lateral aspect; 41, 46, 51-52 - dorsal aspect; $b p$ - proximal bulb. Scale bars: $1 \mathrm{~mm}$.

Рис. 39-52. Эдеагус Trigonaptus gen.n.: 39-43, 49, $51-$ T. longiscapus sp.n.; 44-48, 50, 52 - T. inaequalis sp.n.; 39-41, 44-46средняя доля; 42, 47 - правая парамера, изнутри; 43, 48 - леввая парамера, изнутри; 49-52 - средняя доля с вывернутым и раздутым внутренним мешком; 39, 44, 49-50 - слева; 40, 45 - справа; 41, 46, 51-52 - дорзально; $b p$ — проксимальный пузырь. Масштаб: 1 мм. 
Pronotum: PW/PL 1.21-1.26 (1.23, n=5), PW/HW 1.731.81 (1.78), PLw/PL 0.40-0.42 (0.41); sides rounded, straight in front of basal angles; lateral edge smooth. Base truncate, slightly wider than apex, PB/PA 1.05-1.12 (1.10). Apical angles subrectangular. Reflexed lateral margin slightly flattened in basal third. Basal sulci very smooth, outer one without forward extension.

Elytra fairly long and narrow, EW/EL 1.64-1.69 (1.67), EW/PW 1.11-1.17 (1.13). Humeri distinct yet rounded. Basal ridge inwardly reaching stria 2 , humeral angle obtuse. Striae deep, rather coarsely punctate, $1^{\text {st }}$ continuous basally, $6^{\text {th }}$ inside humeral angle. Intervals equal in width, convex or very so, mostly $3^{\text {rd }}$ and $7^{\text {th }}$ confluent before apex, $7^{\text {th }}$ narrow and subcarinate in apical fifth; $8^{\text {th }}$ very narrow only behind humerus and before apex. USS: 23-24.

Ventral punctation similar, except that punctures are coarser, punctate areas on propleura and mesepisternum less extensive, and sides of metaventrite additionally punctate. Mesoventrite toothed in front of mesocoxa. Metepisternum 0.9 times as long as wide. Abdominal transverse sulci entire.

Metatrochanter apically rounded and slightly separate from metafemur. Meso- and metatarsomeres $1 / 2 / 3$ with 3-4/ $1-2 / 0-1$ anterolateral setae, respectively.

Aedeagus (Figs 39-43): median lobe slightly arcuate, with apex widely rounded in dorsal view, lamellate and slightly upturned in lateral view; right paramere longer and pointed apically. Internal sac (Figs 49, 51) with proximal bulb long, bent to the left and then apicad.

NAME. Latin noun, referring to very long antennal scape.

DISTRIBUTION. Known from the type locality only.

HABITS AND HABITATS. All specimens were hand collected in monsoon broad-leaved forests.
Acknowledgements. This study was funded by the Presidium of the Russian academy of sciences, Program No.41 "Biodiversity of natural systems and biological resources of Russia".

\section{References}

Andrewes H.E. 1931. On the Carabidae of Mt. Kinabalu // Journal Feder. Malay Mus. Vol.16. Pt.3-4. P.431-485.

Andrewes H.E. 1937. Papers on Oriental Carabidae. - XXXI// Ann. Mag. Nat. Hist. Ser.9. Vol.19. P.489-495.

Andrewes H.E. 1939. Papers on Oriental Carabidae. - XXXV // Ann. Mag. Nat. Hist. Ser.11. Vol.3. P.128-139.

Bates H.W. 1892. Viaggio di Leonardo Fea in Birmania e regione vicine. XLIV. List of the Carabidae // Ann. Mus. Stor. Nat. Genova. Ser.2. Vol.12(32). P.267-428.

Dejean P.F.M.A., 1828. Species Général des Coléoptères, de la Collection de M. le Comte Dejean. T.3. Paris. VII+556 p.

Dubault G., Lassale B., Roux P. 2008. les genres des "Trigonotomi": Pareuryaptus $\mathrm{n}$. gen. et révision des Euryaptus Bates, 1892 (Coleoptera, Pterostichidae)// Bull. Soc. Ent. Fr. Vol.113. No.2. P.239-248.

Fedorenko D N 2017. A new subgenus of Pterostichus (Coleoptera: Carabidae: Pterostichini) with 14 new species from Vietnam // Russian Entomol. J. Vol.26. No.3. P.211-238.

Fedorenko D.N. 2018. Notes on Pterostichus subgenus Steropanus (Coleoptera: Carabidae: Pterostichini), with descriptions of new species // Russian Entomol. J. Vol.27. No.2. P.107-121. doi: 10.15298/rusentj.27.2.01.

Fedorenko D.N. 2019. New species of Pterostichus subgenus Circinatus (Coleoptera: Carabidae: Pterostichini) from Vietnam // Russian Entomol. J. Vol.28. No.4. P.358-369. doi: 10.15298/ rusentj.28.4.03

Roux P., Lassale B., Dubault G. 2016. Révision des Trigonotomi (Coleoptera, Pterostichinae). B. Lassale et P. Roux. 569 p. 